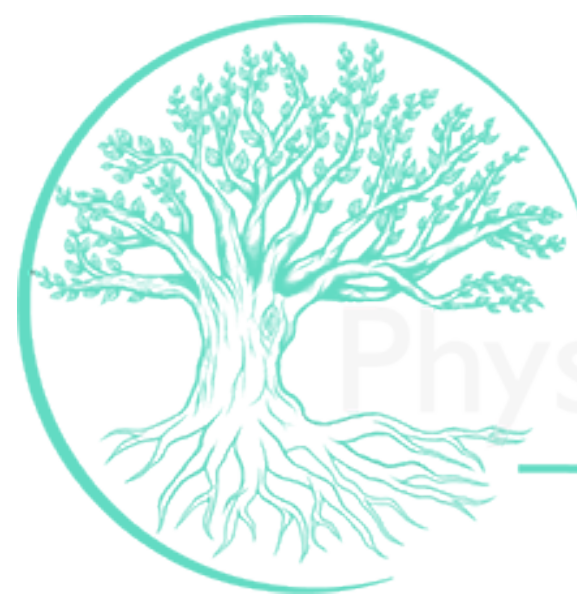

\title{
Implication of Actin in the uptake of sucrose and valine in the tap root and leaf of sugar beet
}

\begin{tabular}{|r|l|}
\hline Journal: & Physiologia Plantarum \\
\hline Manuscript ID & Draft \\
\hline Manuscript Type: & Regular manuscript - Uptake, transport and assimilation \\
\hline Duthor: & nubmitted by the \\
\hline Complete List of Authors: & $\begin{array}{l}\text { Michonneau, Philippe; SCARA } \\
\text { Fleurat-Lessard, Pierrette; Universite de Poitiers, Ecologie \& Biologie des } \\
\text { Interactions, CNRS UMR7267 } \\
\text { Cantereau, Anne; Université de Poitiers, STIM, CNRS ERL6187 } \\
\text { Crepin, Alexandre; Universite de Poitiers, Ecologie \& Biologie des } \\
\text { Interactions, CNRS UMR7267 } \\
\text { Roblin, Gabriel; Universite de Poitiers, Ecologie \& Biologie des } \\
\text { Interactions, CNRS UMR7267 } \\
\text { Berjeaud, Jean-Marc; Universite de Poitiers, Ecologie \& Biologie des } \\
\text { Interactions, CNRS UMR7267 }\end{array}$ \\
\hline Key Words: & $\begin{array}{l}\text { Beta vulgaris, Cytochalasins, Cytoskeleton, sucrose uptake, valine } \\
\text { uptake }\end{array}$ \\
\hline
\end{tabular}



Implication of Actin in the uptake of sucrose and valine in the tap root and leaf of sugar beet

Philippe Michonneau ${ }^{1,2}$, Pierrette Fleurat-Lessard ${ }^{2}$, Anne Cantereau $^{3}$, Alexandre Crépin $^{2}$, Gabriel Roblin ${ }^{2}$, Jean-Marc Berjeaud ${ }^{2 *}$

6

${ }^{1}$ SCARA - Z.I de Villette, 10700 Arcis sur Aube

${ }^{2}$ Université de Poitiers, Laboratoire EBI (Ecologie et Biologie des Interactions), 1 rue Georges Bonnet, TSA 51106, F-Poitiers Cedex 9, France.

${ }^{3}$ STIM CNRS 6187, 1 rue Georges Bonnet, TSA 51106, F-Poitiers Cedex 9, France.

*Corresponding author

E-mail address: J-M. Berjeaud : jean-marc berjeaud @ univ-poitiers.fr

Running title: actin in sucrose and valine uptake

Number of table: 1 


\begin{abstract}
Actin microfilaments (F-actin) are major components of the cytoskeleton essential for many cellular dynamic processes (vesicle trafficking, cytoplasmic streaming, organelle movements). The aim of this study was to examine whether cortical actin microfilaments might be implicated in the regulation of nutrient uptake in root and leaf cells of Beta vulgaris. Using antibodies raised against actin and the AtSUC1 sucrose transporter, immunochemical assays demonstrated that the expression of actin and a sucrose transporter, showed different characteristics, when detected on plasma membrane vesicles (PMVs) purified from roots and from leaves. The in situ immunolabeling of actin and AtSUC1 sites in PMVs and tissues showed their close proximity to the plasma membrane. Using co-labeling in protoplasts, actin and sucrose transporters were localized along the internal border and in the outermost part of the plasma membrane, respectively. This respective membrane co-localization was confirmed on PMVs and in tissues using transmission electronic microscopy. The possible functional role of actin in sucrose uptake (and valine uptake, comparatively) by PMVs and tissues from roots and leaves was examined using the pharmacological inhibitors, cytochalasin $\mathrm{B}(\mathrm{CB})$, cytochalasin $\mathrm{D}(\mathrm{CD})$, and phalloidin $(\mathrm{PH}) . \mathrm{CB}$ and $\mathrm{CD}$ inhibited the sucrose and valine uptake by root tissues in a concentrationdependent manner above $1 \mu \mathrm{M}$, whereas $\mathrm{PH}$ had no such effect. Comparatively, the toxins inhibited the sucrose and valine uptake in leaf discs to a lesser extent. The inhibition was not due to a hindering of the proton pumping and $\mathrm{H}^{+}$-ATPase catalytic activity determined in PMVs incubated in presence of these toxins.
\end{abstract}

Key words: Beta vulgaris, cytochalasins, cytoskeleton, sucrose uptake, valine uptake
Abbreviations: CB: cytochalasin B; CD: cytochalasin D; PH: phalloidin; PMVs: plasma membrane vesicles 


\section{Introduction}

49

The plant cytoskeleton is generally considered to consist of distinct components, e.g. microtubules, microfilaments and intermediary filaments. The microfilament system has been well characterized in plant cells. In particular, actin microfilaments (MFs or F-actin) are highly organized and major components of the cytoskeleton, and are essential for many cellular processes, including division, expansion, and differentiation (Higaki et al. 2007a, and references therein, Hussey et al. 2006, and references therein). Further, dynamic processes, such as vesicle trafficking, cytoplasmic streaming and organelle movements, are also controlled by MFs (Kantasamy and Meagher 1999, Van Gestel et al. 2002). Moreover, the actin cytoskeleton is implicated in plant defense against pathogens (Hardham et al. 2007, Tian et al. 2009), and MF modification is also observed during elicitor-induced vacuolar disintegration in programmed cell death (Higaki et al. 2007b). Plants express multiple actin isoforms, which are dependent on tissues, organs, and stage of development, suggesting that individual isoforms play specific roles in cells, presumably through interactions with specific actin binding proteins (Kijima et al. 2016). Actin and some of the associated proteins are well conserved in plants and animals (Abu-Abied et al. 2006). The association of actin, in particular, with spectrin (Michaud et al. 1991), myosin (Higaki et al. 2007) and Network (NET) superfamily proteins (Deeks et al. 2012) ensures links with plasma membrane and the association with formin connects cytoskeleton to cell wall (Martinière et al. 2011).

Treatments with pharmacological inhibitors such as cytochalasins and phalloidin (PH) have been widely used to examine the role of actin in the above-mentioned processes, although the mechanism of action of these toxins on actin organization differs. Cytochalasin B (CB) alters the conformation of F-actin microfilaments, whereas cytochalasin D (CD) acts by wedging the polymerization of actin $\mathrm{G}$ monomers (Casella et al. 1980), consequently acting more rapidly than CB. Phalloidin $(\mathrm{PH})$ is known to stabilize F-actin filaments by preventing filament depolymerization in response to disruptive agents, including CB (Cooper, 1987). Therefore, PH can be antagonistic to $\mathrm{CB}$ on the actin structure located near the plasma membrane, inducing an abnormal accumulation of actin-containing microfilaments.

Based on the multiple effects of MFs on membrane-linked processes, we examine the role of the cytoskeleton in the uptake of metabolites by plant cells. During plant development, photoassimilates are exchanged between sources, suppliers of metabolites (exporting leaves), and sinks importing metabolites (growing and storage organs). Sucrose export from leaf cells is initiated by SWEET-type transporters and is a prerequisite for loading into the companion cells/sieve element complex (Chen, 2014). Cellular sucrose loading is mediated by transporters belonging to the large SUT/SUC family (Lemoine, 2000). In this last case, $\mathrm{H}^{+}$-ATPase pumps are necessary to energize nutrient uptake at the plasma membrane by sustaining the proton motive 
force (pmf) (Delrot 1981, Sze 1985, Bush 1990, Serrano 1989, Bouché-Pillon et al. 1994, Lemoine et al. 1996, Vaughn et al. 2002). Numerous studies have focused on nutrient loading in the phloem of leaves (Giaquinta, 1977, Delrot, 1981, Gahrtz et al. 1994, Sauer 2007). Recently, Nieberl et al. (2017) characterized the proton-coupled sucrose symporter BvSUT1, that loads sucrose exclusively into companion cells in source leaves of Beta vulgaris. Mechanisms regulating the unloading of nutrients from phloem to sink storage tissues are not yet clearly understood. The transport pathway may be symplastic through plasmodesmata (Esau and Thorsch 1985, Van Bel and Kempers 1990, Van Bel and Gamalei 1991, Lucas et al. 1993, Laurel and Lucas 1996) or apo-symplastic. In sugar storage organs, such as beet taproot, a major fraction of sucrose entering the sink cell is directed toward the vacuole through a specific transporter. Jung et al. (2015) identified the sucrose transporter BvTST2.1 in Beta vulgaris taproot which imports sucrose into vacuoles coupled to the export of protons.

The sugar beet is a biennial plant that accumulates nutrients in its taproot during the first year and uses this store in the second year to form reproductive organs. The tap root represents an original structure: its conducting tissues are organized into concentric rings produced by successive supernumerary cambial layers (Lachaud 1964). Nutrients are stored in xylem parenchyma cells, predominantly in the large and outermost phloem parenchyma cells. Their large central vacuole, whose main content is sucrose and water (Leigh et al. 1979), occupies $90 \%$ of the cell volume and reduces the cytoplasm to a thin layer with high density. Sucrose accumulation in vacuoles induces a strong osmotic pressure which may vary from 12 to 13 bars from the juvenile to the mature stage in root beet cells (Wyse et al. 1986). Consequently, this pressure is contained in two ways, by increased rigidity of the wall which forms an exoskeleton, and through the support of the cortical skeleton.

The aim of this study was to examine whether actin microfilaments may be implicated in the regulation of nutrient uptake by plant cells. First, we demonstrated through immunochemical assays the presence of actin and a sucrose transporter in the plasma membrane, and we examined the differences observed in their respective composition in root and leaf tissues. We also characterized their respective membrane localization on plasma membrane vesicles (PMVs) and in tissues using electronic microscopy. Secondly, we examine the effect of $\mathrm{CB}, \mathrm{CD}$, and $\mathrm{PH}$ on the uptake of sucrose by the root and leaf tissues of sugar beet. Additionally, the activity of these toxins on valine uptake was comparatively examined to determine whether an amino acid transporter also presents comparable physiological responses observed on sucrose transporter. 

Materials and methods

\section{Plant growth conditions}

Sugar beet (Beta vulgaris L. cv Aramis) plants were grown at $20 \pm 1{ }^{\circ} \mathrm{C}$ in a greenhouse on vermiculite under natural day-night conditions. Supplementary lighting was provided with OSRAM 58/10 fluorescent tubes, giving a fluence rate of $80 \mu \mathrm{mol}$ photon $\mathrm{m}^{-2} \mathrm{~s}^{-1}$ from $6.00-9.00$ a.m. and from 7.00-10.00 p.m. Relative humidity was maintained at $60 \pm 10 \%$. The plants were watered daily with Snyder and Carlson (1978) nutritive solution. Plants were used for experiments when they were 4 months old, bore seven mature expanded leaves and had root diameter of approximately $2 \mathrm{~cm}$ (Fig. 1 A).

\section{Transport assays in vivo}

The assays on taproot tissues were carried out as previously described (Michonneau et al., 2004). Tissue cylinders of $12 \mathrm{~mm}$ diameter were taken from the root cortex using a cork borer. These cylinders were sliced into discs of $1 \mathrm{~mm}$ thickness and $0.1100 \mathrm{~g} \pm 0.0013 \mathrm{~g}$ mass and subsequently divided into four quarters of $0.0268 \mathrm{~g} \pm 0.0030 \mathrm{~g}$, to facilitate the uptake of the substrates. The quarters were immersed in a basal medium (BM) containing $300 \mathrm{mM}$ sorbitol, $0.5 \mathrm{mM} \mathrm{CaCl}_{2}$, $0.25 \mathrm{mM} \mathrm{MgCl} 2,20 \mathrm{mM}$ MES (pH 5.4).

Leaf discs (80,6 mm diameter each) were excised after peeling off the lower epidermis and incubated (peeled face downwards) on BM. Harvesting was carried out in areas containing only minor veins.

Radiolabeling studies were carried out on root tissue quarters and leaf discs in BM containing $1 \mathrm{mM}\left[{ }^{14} \mathrm{C}\right]$ sucrose (final activity $11 \mathrm{kBq} \mathrm{ml}^{-1}$ ) and $1 \mathrm{mM}\left[{ }^{3} \mathrm{H}\right]$ valine (final activity $9.25 \mathrm{kBq} \mathrm{ml}^{-}$ $\left.{ }^{1}\right)$. Incubation was run for $30 \mathrm{~min}$ under mild agitation on a shaker at $25^{\circ} \mathrm{C}$. At the end of the incubation, the root quarters were rinsed $(3 \times 3 \mathrm{~min})$ in $\mathrm{BM}$ and were placed in scintillation vials. Solubilization of the tissues occurred at $55^{\circ} \mathrm{C}$ during $24 \mathrm{~h}$ in a mixture of perchloric acid (56\%), $0.1 \% \mathrm{H}_{2} \mathrm{O}_{2}(27 \%)$, and Triton X-100 (17\%). Discs of exporting leaves were treated in the same way except that the mixture used for solubilization consisted of perchloric acid (25\%), $\mathrm{H}_{2} \mathrm{O}_{2}$ (50\%) and Triton X-100 (25\%). Finally, $4 \mathrm{ml}$ of scintillation liquid (Ecolite ${ }^{\mathrm{TM}}$, ICN) was added to the tubes and radioactivity was counted by liquid scintillation spectroscopy (1900 TR Packard).

\section{Preparation of protoplasts}

Protoplasts were prepared from the taproot and leaf blade according to Fleurat-Lessard et al. (1993). Tiny slices of root tissues and peeled leaf discs were stored in the predigestion medium (0.6 M mannitol, $25 \mathrm{mM}$ MES, $8 \mathrm{mM} \mathrm{CaCl}_{2}$ and $2 \mathrm{mM} \mathrm{MgCl}_{2}$ at $\mathrm{pH} 5.6$ ) for $1 \mathrm{~h}$ at $28^{\circ} \mathrm{C}$ to be 
plasmolyzed. Digestion occurred in the dark for $2 \mathrm{~h}$ at $30^{\circ} \mathrm{C}$ in the same medium, supplemented with 1.5\% pectolyase (Seishin Pharmaceutical Co., LTD, Tokyo, Japan), 2\% macerozyme R-10 and 3\% cellulase (Yakult, Pharmaceutical Industry Co., Ltd, Nishinomiya, Japan). Then, protoplasts (60 to $80 \mu \mathrm{m}$ in width) were isolated at $4^{\circ} \mathrm{C}$ on a Ficoll gradient by a $30 \mathrm{~min}$ centrifugation at $900 \mathrm{~g}$.

\section{Isolation and uses of plasma membrane vesicles from root and leaf tissues}

Purified PMVs were prepared by phase partitioning of microsomal fractions from the leaf and root tissues of sugar beet according to Lemoine et al. (1991) with some minor modifications. The PMVs at a concentration of $15 \mu \mathrm{g} \mathrm{ml}^{-1}$ were equilibrated in a medium containing $0.3 \mathrm{mM}$ sorbitol, $50 \mathrm{mM}$ potassium phosphate ( $\mathrm{pH} 7.5$ ), $0.5 \mathrm{mM} \mathrm{CaCl}_{2}, 0.25 \mathrm{~mm} \mathrm{MgCl}_{2}$, and $0.5 \mathrm{mM}$ DTT, frozen in liquid nitrogen and stored at $-80{ }^{\circ} \mathrm{C}$. The PMVs were placed in the inside-out configuration by adding $0.05 \%$ Brij in the assay medium. In the four batches of vesicles used in this work, treatment with the plasma membrane $\mathrm{H}^{+}$-ATPase inhibitor sodium orthovanadate at $0.25 \mathrm{mM}$ (Gallagher and Leonard, 1982; O'Neill and Spanswick, 1984) showed that 75\% of the enzyme activity can be attributed to plasma membrane functioning. Vanadate-sensitive ATPase activity of the PMVs was measured in a medium buffered with $50 \mathrm{mM}$ tris-maleate at a $\mathrm{pH}$ of 6.9 (Noubhahni et al., 1996). Proton pumping was measured by the decrease of 9aminoacridine absorbance at $495 \mathrm{~nm}$ in a medium buffered with $10 \mathrm{mM}$ tris-maleate at a $\mathrm{pH}$ of 6.9 (Noubhahni et al., 1996). The reaction was initiated by the addition of $3 \mathrm{mM} \mathrm{MgSO}_{4}$ to the medium. Protein content was measured using the method of Bearden (1978).

When measuring the uptake of sucrose and valine, PMVs were placed in an "energized" state following resuspension in $50 \mathrm{mM}$ sodium phosphate ( $\mathrm{pH}$ 5.5), containing $10 \mu \mathrm{M}$ valinomycin (condition creating $\mathrm{pH}$ and $\Psi$ gradients) (Lemoine et al., 1991). Uptake assays were carried out as previously described (Michonneau et al., 2004). Briefly, uptake was initiated by rapidly mixing vesicles with the incubation medium containing $1 \mathrm{mM}\left[\mathrm{U}_{-}{ }^{14} \mathrm{C}\right]$ sucrose (final activity: $27 \mathrm{kBq} \mathrm{ml}^{-1}$ ) and $1 \mathrm{mM}\left[{ }^{3} \mathrm{H}\right]$ valine (final activity: $41 \mathrm{kBq} \mathrm{ml}^{-1}$ ). Uptake was stopped after $3 \mathrm{~min}$ by adding $2 \mathrm{ml}$ medium containing $5 \mathrm{mM} \mathrm{HgCl}_{2}$. The content of the test tubes was filtered using Millipore HAWP filters (pore size $0.45 \mu \mathrm{m}$ ). The filters were then rinsed, placed in a scintillation vial, dried at 50 ${ }^{\circ} \mathrm{C}$ for $1 \mathrm{~h}$, and immersed in $4 \mathrm{ml}$ of scintillation liquid for counting. In the dedicated experiments, inhibitors (Vanadate, $\mathrm{CB}, \mathrm{CD}, \mathrm{PH}$ ) were added to the PMV incubation medium, 30 min before determining $\mathrm{H}^{+}$-ATPase activity and uptake of sucrose and valine.

\section{Electrophoresis and immunological assays}


SDS-PAGE was performed according to Laemmli (1970) using $10 \%$ polyacrylamide, $0.21 \%$ bisacrylamine gels. The gels were run at room temperature under a constant current of $15 \mathrm{~mA}$. The gels which were equilibrated in $25 \mathrm{mM}$ tris, $192 \mathrm{mM}$ glycine and $20 \%$ methanol at a $\mathrm{pH}$ of 9.4, were electrotransferred onto nitrocellulose (Towbin et al., 1979) for $1 \mathrm{~h}$ at $200 \mathrm{~mA}$. After the saturation of the non-specific sites, incubation with the primary antibody was performed in phosphate buffer saline (PBS) plus $0.1 \%$ BSA for $90 \mathrm{~min}$ at $10{ }^{\circ} \mathrm{C}$. A anti-actin antibodies raised in mice (ICN, 691002, titer $1 \mathrm{mg} \mathrm{ml}^{-1}$ ) were used. Anti-AtSUC1 antibodies raised in rabbit (a kind gift from Professor Ruth Stadler, University of Erlangen, Germany) against the sucrose carrier 1 of Arabidopsis thaliana as described by Sauer and Stolz (1994) has been successfully experimented on sugar beet by Sakr et al. (1997). Interestingly, the expression of AtSUC1 was observed in many tissues (Feuerstein et al. 2010), particularly in roots (Sivitz et al. 2008). After rinsing, the secondary antibody, GAM-peroxidase for actin and GAR-peroxidase for AtSUC1 (Biorad, Marnes la Coquette, France), diluted at 1/2000 in the saturation medium was used. The antigen-antibody complex was examined using the kit ECL RPN 2106 (GE Healthcare Europe $\mathrm{GmbH}$ ) which contained the substrate of the conjugate peroxidase. The subsequent light emission was monitored on film (Hyperfilm, GE Healthcare Europe GmbH) treated with 1/10 Ilford Ilfotec LC 29 and 1/10 Ilford Rapid Fixer. The positions of the bands were compared with the molecular weight of prestained standards (SeeBlue ${ }^{\mathrm{R}}$ Plus2, Invitrogen).

\section{Microscopy and in situ immunolocalization}

Protoplasts isolated from the taproot and leaf blade were examined with a spectral confocal station FV1000 which was installed on an inverted microscope IX-81 (Olympus, Tokyo, Japan). Double fluorescence images were acquired sequentially with an Olympus UplanFLN x 40 oil, $1.3 \mathrm{NA}$ objective lens. Green fluorescence was excited with the $488 \mathrm{~nm}$ line of an argon laser and the emitted fluorescence was detected through a spectral detection channel between 500 and $530 \mathrm{~nm}$. Red fluorescence was obtained sequentially with a $543 \mathrm{~nm}$ line of a $\mathrm{HeNe}$ laser and detected through a channel between 555 and $655 \mathrm{~nm}$. Images were maximum intensity projections which resulted from the optical sectioning of the specimen (20-60 sections, $1 \mu \mathrm{m}$ step). The localization of actin and AtSUC1 in protoplasts was obtained by applying the antibodies either separately or simultaneously to achieve a co-localization of both components. F-actin was identified via the tetramethylrhodamine isothiocyanate (TRITC)-phalloidin probe that emits red fluorescence and AtSUC1 via the fluorescein isothiocyanate (FITC) probe that emits green fluorescence.

For transmission electron microscopy (TEM), the samples of plant tissues were treated as previously described (Bouché-Pillon et al. 1994; Fleurat-Lessard et al. 1997). Briefly, samples were fixed for $45 \mathrm{~min}$ at $4^{\circ} \mathrm{C}$ in $2 \%$ paraformaldehyde $/ 0.5 \%$ glutaraldehyde $(\mathrm{w} / \mathrm{v})$ prepared in Sörensen buffer at $\mathrm{pH}$ of 7.4, washed extensively in the buffer containing 7.5\% sucrose, postfixed 
in $1 \%(\mathrm{v} / \mathrm{v})$ osmium tetroxide, dehydrated in an increasing ethanol series, and embedded in London Resin White (LRW) by polymerization conducted at $60^{\circ} \mathrm{C}$ for $24 \mathrm{~h}$. Ultrathin sections (70 nm thick) of these chemically fixed samples were collected on gold grids and immunotreated. Briefly, the samples on the grids were rehydrated and treated with $0.5 \mathrm{M} \mathrm{NaIO}_{4}$ for $25 \mathrm{~min}$ and $0.1 \mathrm{M} \mathrm{HCl}$ for $8 \mathrm{~min}$ to expose the antigen sites. The non-specific sites were saturated by the addition of 10 mM PBS (pH 7.2), 0.1\% Triton X-100, 0.2\% Tween 20, 0.1\% BSA and 1/20 normal goat serum (NGS, Nordic, TEBU, Le Perray en Yvelines, France) for three times for 5 min each). The primary antibody (see western blot analyses) was diluted at 1/50 in the saturation medium and added to the samples followed by overnight incubation at $4^{\circ} \mathrm{C}$. The grids were then saturated using Tris-buffered saline (TBS) (pH 8.2), 0.1\% Triton X-100, 0.2\% Tween 20, 0.1\% BSA, 1/20 NGS for $1 \mathrm{~h}$. The secondary antibody coupled to gold particles (15 nm size) (EM GAR $15 \mathrm{~nm}$, Biocell, TEBU) was applied to the TBS solution for $3 \mathrm{~h}$.

Immunolabellings of actin and AtSUC1 were done on ultrathin sections which were obtained from the tissues and on purified fractions of PMVs which were isolated from roots and leaves. They were fixed and embedded as described above. Anti-actin and anti-AtSUC1 were added to the saturation medium at a 1/30 dilution. The co-localization of actin and AtSUC1 was achieved using 1/50 diluted secondary antibodies which were applied together and labeled with gold particles of different sizes, including $5 \mathrm{~nm}$ for actin (EM GAM $5 \mathrm{~nm}$, Biocell, TEBU) and $10 \mathrm{~nm}$ for AtSUC1 (EM GAR $10 \mathrm{~nm}$, Biocell, TEBU). After washing in TBS (three times for $15 \mathrm{~min}$ ) and distilled water for $15 \mathrm{~min}$, the samples on the grids were contrasted and observed in TEM using a JEM 1010 Jeol microscope operating at $80 \mathrm{kV}$.

Three independent immunoassays were performed. Counting was made using pictures obtained from six samples of PMVs and tissues from the leaves and roots. Five to eight pictures from each sample were analyzed. Controls were obtained by omitting the primary antibody from the experiment.

\section{Chemicals}

Stock solutions of the effectors were prepared as follows: $\mathrm{CB}$ at $0.240 \mathrm{mg} \mathrm{ml}^{-1}(500 \mu \mathrm{M})$ in distilled water containing ethanol (30\%), CD at $5 \mathrm{mg} \mathrm{ml}^{-1}(10 \mathrm{mM})$ prepared in pure DMSO and $\mathrm{PH}$ at $7.90 \mathrm{mg} \mathrm{ml}^{-1}(10 \mathrm{mM})$ was dissolved in $100 \%$ ethanol. Control tissues were treated at the maximum by $0.6 \%$ ethanol or $0.1 \%$ DMSO. 


\section{Results}

\section{Anatomical and cytological characteristics of the root and leaf tissues}

During the development of the Beta root, cambium produced the secondary phloem and xylem. These secondary structures expanded considerably because of the increase in the number and width of pericycle and associated vascular cells distributed in concentric layers. At the harvesting stage, the differentiation of supernumerary cambium has led to the formation of six or seven concentric layers of vascular tissues which were separated by large pericycle areas as shown in the autoradiographic images obtained after treatment with $\left[{ }^{14} \mathrm{C}\right]$ sucrose (Fig. 1B). From this image, one can deduce that the vascular tissue layer (composed of conducting elements surrounded by parenchyma in vascular bundles and by interfascicular parenchyma) was about one-third the thickness of the storage pericycle layer (Fig. 1C). Storage pericycle cells (60-70 $\mu \mathrm{m}$ wide) were characterized by a large central vacuole that flattened the thin cytoplasm and the nucleus against the pectocellulosic wall (thicker than the cytoplasm) (Fig. 1D, D').

In the leaf discs, $\left[{ }^{14} \mathrm{C}\right]$ sucrose labeling was observed mainly in the veins and mesophyll cells (Fig. 1E). The determination of the respective areas from this cross-sectioned image indicated that mesophyll cells occupied half of the total area. Cross sections of a small leaf vein (approximately $60 \mu \mathrm{m}$ wide) showed that xylem and phloem tissues, which were surrounded by the bundle sheath, were surrounded by several layers of large mesophyll cells (each at least 60 $\mu \mathrm{m}$ wide and $100 \mu \mathrm{m}$ long) (Fig. 1F). The mesophyll cells contained large vacuoles and several plastids with starch grains and wide nuclei (Fig. 1G). Additionally, the cytoplasm of the leaf cells was thicker than that of the root cells.

\section{Co-localization of actin and a putative sucrose carrier in storage root cells and in mesophyll cells of sugar beet}

As shown by the western blot analysis of the PMVs (Fig. 2), using an antibody raised against actin, labeled actin was localized at $42 \mathrm{kDa}$ on protein extracts of roots and leaves. The quantity of actin was in lower amounts in the leaf extracts than the root extracts. The anti-AtSUC1 antibody, raised against the sucrose transporter SUC1 from Arabidopsis was chosen because of its high expression as well in leaves as in roots (Sivitz et al. 2008). It labeled three protein bands in root extracts (two main bands at 42 and $56 \mathrm{kDa}$ and a band of low intensity at $46 \mathrm{kDa}$ ) and a distinct band in leaf extracts at $42 \mathrm{kDa}$.

However, to examine the possible structure and function link, the involved element must be localized in an appropriate place in the cell. To address this issue, subcellular localization was carried out on the PMVs isolated from the root and leaf tissues. An immunogold labeling detected on PMVs purified from roots and leaves, using antibodies raised against actin (Fig. 3A, D) and 
the sucrose transporter AtSUC1 (Fig. 3B, E) compared with the control treatment (Fig. 3C, F) specified the localization of both proteins in the purified membrane fraction. As shown in ultrathin sections of the storage root cells (Fig. 4A, B, C) and of leaf parenchyma cells (Fig. 4D, E, F), labeling with gold particles confirmed the subcellular localization of both components. The labeling of the sucrose carrier appeared to be localized in the outer region of the membrane compared with the labeling of actin which was localized in the internal region. It is important to emphasize that no labeling was observed on the vacuolar membrane.

The in situ immunolocalization revealed that labeled actin and sucrose carriers were detected in the cortical area of the protoplasts of the root storage cells (Fig. 5A, B, C, D, E) and mesophyll cells (Fig. 5F, G, H, I, J). However, the sucrose carrier appeared to be localized externally compared with the actin in both types of protoplasts (Fig. 5D, I). Furthermore, the immunolabeling observed in electron microscopy, using gold-labeled secondary antibodies which were applied simultaneously (EM GAR $10 \mathrm{~nm}$ for sucrose transporter and EM GAM $5 \mathrm{~nm}$ for actin), allowed the determination of the distance separating the two sites. The distance measured between the large and small gold particles was $44 \pm 3 \mathrm{~nm}($ mean $\pm S E ; n=30)$ in the PMVs from the roots (Fig. 6A) and $48 \pm 4 \mathrm{~nm}(\mathrm{n}=30)$ in the PMVs from the leaves (Fig. 6B). In tissues, the distance was $45 \pm 4 \mathrm{~nm}(\mathrm{n}=42)$ in the root cells $($ Fig. 6D) and $44 \pm 2 \mathrm{~nm}(\mathrm{n}=48)$ in the mesophyll cells (Fig. 6E). However, Student Fisher $t$ test showed that the differences were not statistically significant at 5\% confidence level. Gold labeling was absent in controls obtained after primary antibody omission, as shown in the PMVs (Fig. 6C). In addition, it should be stressed that the colocalization indicated that labeled sites were not located in definite microdomains.

\section{Effect of cytochalasin B, cytochalasin D, and phalloidin on sucrose and valine uptake} by beet tissues

To determine whether actin may be functionally implicated in the activity of transporters, we tested known inhibitors of actin microfilament arrangement, namely $\mathrm{CB}, \mathrm{CD}$ and $\mathrm{PH}$.

In line with previously reported data (Michonneau et al., 2004) the capacity of sucrose uptake by the root tissues increased continuously and considerably until $12 \mathrm{~h}$ of aging in the control samples (Fig. 7A). This phenomenon has been largely investigated in leaf tissues (Sakr et al., 1993; 1997) (Fig. 7B). After this period, a significant decrease in net sucrose uptake was observed, particularly in the root tissues. $\mathrm{CB}, \mathrm{CD}$ and $\mathrm{PH}$ did not control the sucrose uptake in the roots and in leaves with the same intensity (Fig. 7A, B). Additionally, increasing the treatment duration from 3 to 6,12 , and $24 \mathrm{~h}$ increased the inhibition of net sucrose uptake in the roots from 5 to 20,37 and $57 \%$ for $\mathrm{CB}$ and from 0 to 17, 24 and 34\% for CD, respectively (Fig. 7A). Additionally, during increase in treatment duration from 3 to 6,12 , and $24 \mathrm{~h}, 10 \mu \mathrm{M} \mathrm{CB}$ inhibited 
uptake in the leaves from $8,18,18$, and $5 \%$, while $10 \mu \mathrm{M} \mathrm{CD}$ inhibited uptake from 7 to 14,7 and 10\% (Fig. 7B). Sucrose uptake was significantly inhibited in the roots and leaves after $6 \mathrm{~h}$ treatment with the toxins. Under the same conditions, $10 \mu \mathrm{M}$ PH did not significantly modify the sucrose uptake capacity of the root tissues, however, it transiently inhibited the uptake in the leaf tissues. In this case, increasing the treatment duration from 3 to 6,12 , and $24 \mathrm{~h}$ inhibited sucrose uptake from 12, 29, 21 and 1\%, respectively (Fig. 7B).

Comparative assays showed that valine uptake was also modified by the inhibitors with similar characteristics as in sucrose uptake, although with some differences in the extent of their action. The capacity of valine uptake by root and leaf tissues showed an aging process and was more affected in roots tissues treated with $\mathrm{CB}$ and $\mathrm{CD}$ than in leaf tissues (Fig. 7C, D). Increasing the treatment duration from 3 to 6,12 , and $24 \mathrm{~h}$ increased the inhibition of net valine uptake in the roots respectively from 29 to 36,50 and $71 \%$ for $10 \mu \mathrm{M} \mathrm{CB}$ and from 14 to 28,25 and $35 \%$ for $10 \mu \mathrm{M}$ CD, respectively (Fig. 7C). Increasing the treatment duration_from 3 to 6, 12, and $24 \mathrm{~h}$ increased uptake inhibition in the leaves from 19 to 20,17 , and $17 \%$ for $10 \mu \mathrm{M} \mathrm{CB}$ and from 10 to 14,10 and $7 \%$ for $10 \mu \mathrm{M}$ CD (Fig. 7D). Furthermore, CB and CD acted more rapidly on the valine uptake capacity, since a significant inhibition was observed after $3 \mathrm{~h}$ treatment duration. Note that $10 \mu \mathrm{M}$ PH did not significantly modify the uptake capacity of valine in roots and leaves. Notably, above the threshold value of $1 \mu \mathrm{M}$, the inhibition of sucrose and valine uptake observed on root and leaf tissues treated for $12 \mathrm{~h}$ with $\mathrm{CD}$ and $\mathrm{CB}$ was dose-dependent (Fig. 8A, B, C, D).

\section{Effect of cytochalasin B, cytochalasin D and phalloidin on the uptake of sucrose and valine by plasma membrane vesicles purified from root and leaf tissues}

The PMV model allows us to examine the sucrose transporter expressed in the mesophyll cells and in storage parenchyma cells of roots, which represent the more abundant cell type in the tissues. The use of the "energized" PMVs allowed to determine if the toxins may act on the activities of the transporters through a side effect, resulting from an inhibition of the cell metabolism. Proton motive force (pmf)-driven uptake of sucrose and valine was significantly reduced in PMVs from roots treated with CB (by 18\% and 20\%, respectively) and CD (by $18 \%$ and $31 \%$, respectively), whereas it appeared to be significantly unaffected in PH-treated PMVs (Fig. 9A, C). Comparatively, the uptake of sucrose and valine was also significantly inhibited in PMVs purified from leaves treated with CB (18\% and 15\%, respectively), but was unaffected in PMVs treated with CD (Fig. 9B, D). However, PH inhibited sucrose uptake in PMVs purified from leaves, whereas it did not significantly affect valine uptake (Fig. 9B, D). Therefore, a close parallelism in the action of the compounds can be observed in tissues and in PMVs purified from 
the respective tissues, strongly suggesting that the inhibitors acted directly through a modification at the plasma membrane level.

\section{Effect of cytochalasin B, cytochalasin D and phalloidin on $\mathbf{H}^{+}$-ATPase activity}

In order to verify that the different inhibitors did not act indirectly through a modification of the plasma membrane $\mathrm{H}^{+}$-ATPase activity, which energizes the $\mathrm{H}^{+}$co-transport of sugars and amino acids, we first assayed $\mathrm{CB}, \mathrm{CD}$ and $\mathrm{PH}$ on the $\mathrm{H}^{+}$fluxes occurring in the plant tissues. As previously shown, a continuous acidification over a period of $5 \mathrm{~h}$ was observed in the incubation medium of root quarters, the $\mathrm{pH}$ decreasing from 6.3 to 5.5 (Michonneau et al. 2004). A similar observation has been made in the incubation medium of leaf tissues (Delrot 1981). In both experimental models, fusicoccin, a well-known $\mathrm{H}^{+}$-ATPase activator (Marrè 1979), increased the rate of acidification.

The results of the assays showed that the decrease in $\mathrm{pH}$ of the control medium containing the root and leaf tissues was similar to the observed trend in media containing $\mathrm{CB}, \mathrm{CD}$, and $\mathrm{PH}$ at the concentrations previously used in the uptake experiments, indicating that the excretion of protons was not altered in the treated tissues (results not shown). Additionally, we examined the effect of the direct application of the compounds on the PMVs on the $\mathrm{H}^{+}$-ATPase activity. $\mathrm{CB}, \mathrm{CD}$, and PH used at low concentrations ( $1 \mu \mathrm{M}$ and $10 \mu \mathrm{M})$, did not significantly modify the transmembrane proton pumping and the vanadate-sensitive enzyme catalytic activity of the vesicles; however, the inhibition of both activities was induced at $50 \mu \mathrm{M}$ (Table 1).

Taken together, our results indicated that $\mathrm{CB}, \mathrm{CD}$, and $\mathrm{PH}$ did not affect the uptake of sucrose and valine at the concentration used through a side effect by acting on the $\mathrm{H}^{+}$-ATPase, but achieved their inhibitory effect by acting directly on a physiological process that regulates the activity of the transporters. 
Discussion

\section{Differential effects of cytochalasins and phalloidin on sucrose and valine uptake}

Previous studies have shown that the uptake of sucrose and amino acids occurs through an active process mediated by plasma membrane carriers which used an $\mathrm{H}^{+}$-substrate co-transport mechanism in leaf cells (Delrot et al. 1980, Bush 1989, Lemoine and Delrot 1989) and tap root cells (Michonneau et al. 2004). The presence of carriers supports the idea that nutrient fluxes are apoplastic (without ruling out the symplastic way). The mesophyll cells in plants behave like sources and are involved in unloading processes before the loading of sucrose and amino acids in the phloem cells for long-distance transport. However, under the experimental conditions used in the present study, the leaf disc model has been widely used to study the mechanisms of nutrient transport with significant results (Delrot 1981, Sakr et al. 1993). Under these conditions, the direction of transport may be reversed depending on the direction of the nutrient gradient, $\mathrm{pH}$ or transmembrane potential, as reported for ZmSUT1, the sucrose carrier in Zea mays (Carpaneto et al. 2005).

Our results showed that the pattern of sucrose and valine uptake was organ-specific. The capacity of valine uptake was however 3- and 2-fold higher than that of sucrose uptake, as well in the roots as in the leaves as previously noted (Sakr et al. 1997, Michonneau et al. 2004). Nevertheless, the uptake pattern had some similarities, particularly, the uptake capacity asymptotes at $12 \mathrm{~h}$, indicating that a net loss of substrate pool sizes occurred through either metabolic use or leakage back to the medium.

$\mathrm{CB}, \mathrm{CD}$, and PH differentially modified nutrient transport in beet plant tissues. $\mathrm{CB}$ had a stronger inhibitory on sucrose and valine uptake in both roots and leaves than $\mathrm{CD}$. In contrast, $\mathrm{PH}$ had no effect, except on sucrose uptake in leaf tissues. Furthermore, the uptake of sucrose and valine was more inhibited in the root cells by $\mathrm{CB}$ and $\mathrm{CD}$ than in the leaf cells, suggesting that nutrient transport regulation differs in mesophyll and root storage cells. Similarities in the modification of sugar transport by the toxins used can be drawn from comparative data reported on animal cells. The different toxins examined have been extensively used as tools to determine the characteristics of sugar transport in several animal cell models. In particular, CB has been shown to inhibit the transport of glucose in several mammalian cell lines (Mizel and Wilson 1972), to reversibly alter hexose transport, glucosamine (Allen et al. 1980), a D-2-deoxyglucose uptake in leucocytes and fibroblasts (Zigmond and Hirsch 1972) and sugars in erythrocytes (Lin and al. 1978), in enterocytes (Uezato and Fujita 1986), and renal cells (Silverman and Turner 1982, Cheung and Hammerman 1988). Additionally, studies have reported that the action of CD is reduced in red blood cells (RBC) sugar transport compared with the action of CB (Leitch and 
Carruthers, 2009) and this observation has been linked with the lower binding affinity of CD to the GLUT1 transporter (Rampal et al. 1980, Leitch and Carruthers 2009).

\section{Possible effect of the toxins on sucrose uptake through a direct action on the transporter}

Since the plasma membrane $\mathrm{H}^{+}$-ATPase activity in PMVs was not modified by the toxins at the concentrations used (Table 1), the observed inhibitory action on sucrose uptake cannot be ascribed to an indirect effect, such as the modification of the driving pmf. Therefore, in light of the knowledge concerning the effects of the toxins on animal cells, it can be assumed that the toxins had a direct effect on the transporters. However, there is need for further studies on plant materials. Several studies have shown that the activity of GLUT family of transporters, which were localized in various tissues, was inhibited by $\mathrm{CB}$ at the concentration used in this work (Kellett et al. 2008, Augustin 2010). Previous studies have reported that in glucose transport in erythrocytes which is mediated by the transport protein GLUT1 (Mueckler et al. 1985), CB acted as an endofacial site inhibitor in the RBCs (Krupka and Devés, 1980) and renal proximal tubular cells (Cheung and Hammerman 1989). Jung and Rampal (1977) showed that CB binding to PMVs from RBC is multisite and a site, corresponding to the functional GLUT1 transport, accounts for $30 \%$ of the total CB binding sites. In the second mode of glucose uptake which has been observed particularly in intestine and kidney cells, glucose absorption was achieved through sodiumdependent sugar transporters (SGLTs), and the glucose is co-transported with $\mathrm{Na}^{+}$via an electrochemical gradient across the membrane, which is maintained by the $\mathrm{Na}^{+} / \mathrm{K}^{+}$pump (Kellett et al. 2008, Harada and Inagaki 2012). Characteristically, this co-transport is directly inhibited by the plant glucoside phloridzin which is reported to be a potent competitive inhibitor of glucose transport in intestine and kidney cells (Wright et al. 2011). Although phloridzin has been shown to inhibit the uptake of glucose and sucrose in broad bean tissue (Lemoine et al. 1987), the inhibition of sucrose and valine uptake observed in the present study could not be attributed to SGLTs without undertaking further analysis. This is because we have observed that phloridzin had a high inhibitory effect on proton pumping and the $\mathrm{H}^{+}$-ATPase activity of PMVs from beet leaves at a concentration of $5 \mathrm{mM}$ (unpublished data). Therefore, the observed inhibition of uptake following phloridzin application may be due to the strong protonophore effect of the compound.

Western blot analysis conducted with the AtSUC1 antibody revealed one band at $42 \mathrm{kDa}$ in the leaf cells, confirming the results of Gallet et al. (1992), Sakr et al. (1997) and Li et al. (1994). A supplementary isoform was observed at $56 \mathrm{kDa}$ in the tap root cells. Similarly, a band corresponding to a sucrose carrier was observed at $55 \mathrm{kDa}$ in the leaves of Spinacea oleracea (SoSUT1) (Riesmeier et al. 1992), at $54 \mathrm{kDa}$ in the leaves of Plantago major (PmSUT2) (Gahrtz et al. 1994) and Solanum tuberosum (Krügel et al. 2008), and at $50 \mathrm{kDa}$ in the leaves of B. vulgaris (Nieberl et al. 2017). Therefore, we cannot exclude the fact that the antibody recognized the two 
different sucrose transporters expressed in the different cell types. Therefore, it can be inferred that the higher inhibitory effect of $\mathrm{CB}$ on sucrose uptake in roots may be linked to the $\mathrm{CB}$ binding to the $56 \mathrm{kDa}$ component.

\section{Possible effect of the toxins on nutrient uptake by modifying the functionality of the cytoskeleton}

466

467

468

469

470

471

472

473

474

475

476

477

478

479

480

481

482

483

484

485

486

487

488

489

490

491

492

493

494

495

The effect of $\mathrm{CB}$ and $\mathrm{CD}$ cannot be restricted to inhibition of the activity of the sucrose transporter, as evidenced by their strong inhibitory effect also observed on amino acid uptake. This led us to believe that a component of the compounds' action may be linked to a general plasma membrane process. The inhibition of the uptake of valine and sucrose by CB and CD showed a similar trend; however, their inhibitory effect was stronger in root cells than in leaf cells. Contrarily, PH did not significantly inhibit the uptake of sucrose and valine in the experimental samples. Furthermore, the lack of specificity in the action of $\mathrm{CB}$ on sugar transport has been previously reported in some animal cells (Estensen et al., 1972). Zhang and Ismail-Beigi (1988) suggested that the toxins ( $\mathrm{CB}, \mathrm{CD}$, and $\mathrm{PH})$ do not only act specifically on the transporters GLUT1, GLUT2, but bind to membranes and modify the organization of the cytoskeleton. They reported that the binding of cytochalasin E (CE) to actin filament_resulted in a conformational change in proteins that are closely associated with GLUT1, leading to the unmasking of the transporter. Additionally, it has been shown in RBCs that $30 \%$ of the total CB binding sites correspond to actin sites (Jung and Rampal 1977). Similarly, cytoskeletal rearrangement has been linked with the activity of $\mathrm{Na}^{+}$-dependent sugar transporter SGLT1 in kidney and intestinal cells (Hediger et al. 1987, Pappenheimer et al. 1987, Kellett et al. 2008). Furthermore, Diez and Sanpedro (2000) reported that the inhibitory effect of CE on the intestinal SGLT1 was secondary to its action on the cytoskeleton through protein structure modification.

Generally, in light of the effects induced by the different tested toxins on the processes of cytokinesis and cell motility, these reports lead to the consideration of the general role played by microfilaments in plant cell physiology (Pollard and Borisy 2003). Actin filaments are widespread (Parthasarathy et al. 1985) and form a network, which is closely bound to the plasma membrane and influence the functioning of intrinsic membrane proteins through topographic modifications and the specific dynamics of the plasma membrane (Lopez et al., 1994). Besides its involvement in cytoplasmic streaming which allows movements of vesicles and organelles (Williamson 1979, Parthasarathy et al. 1985, Staiger and Schliva 1987), actin is known to intervene in the structural integrity of the plasma membrane/cytosol interface in plant cells (Schmit and Lambert 1988). The accumulation of sucrose in the vacuole of root storage cells induces the development of a strong osmotic pressure (900 mosmol) (Leigh et al. 1979), which may result in a compressive stress on the thin cytoplasm layer (less than $1 \mu \mathrm{m}$ thick) orthogonally to the wall. This situation in root 
496

497

498

499

500

501

502

503

504

505

506

507

508

509

510

511

512

513

514

515

516

517

518

519

520

521

522

523

524

525

526

527

528

529

530

531

532

cells should be associated with an original cytoskeleton organization, which may control the balance between vacuole and wall pressures. Therefore, a modification of the cytoskeleton structure may affect the membrane processes involved in exchanges between the symplast and apoplast. The short distance (averaged $40 \mathrm{~nm}$; Fig. 6) between actin and AtSUC1 sites, which were identified by the gold-labeled antibodies, suggests that a functional relationship may exist between the sucrose carrier and actin microfilaments in the vicinity of the plasma membrane. This short distance may be occupied by actin binding proteins that regulate the assembly/disassembly of actin monomers along the actin filaments (approximately $0.9 \mathrm{~nm}$ wide) and are also expected to control the anchoring with cytoskeletal proteins such as villin, formin, myosin, and spectrin (Higaki et al. 2007, Martinière et al. 2011), and possibly with plasma membrane transport proteins. Additionally, Tsakiridis et al. (1994) reported that spectrin specifically associated with GLUT4 transporter created a direct interaction between glucose transporter containing vesicles and actin network. CD, which disassembled the actin network affected the recruitment of preformed vesicles in intracellular organelles to the plasma membrane. Such a long-term effect may be compatible with the observed time course of sucrose uptake inhibition in the present study (Fig. 7).

Western blot analysis showed that actin was quantitatively more represented in root cells than in leaf cells (Fig. 2). This would explain in part why the drug action on actin microfilaments affected the uptake capacity in the root cells more strongly than in the leaf cells. However, this hypothesis should be further verified since only one isoform of actin was identified through the western blot analysis, whereas plant actins are encoded by multigene families, leading to distinct classes of tissue-specific actin RNA (McLean et al. 1990) which may encode actins with different functions in roots and leaf cells. Additionally, immunodetection of spectrin in PMVs from the leaf and root tissues and the number of immunolocalized sites in TEM observations suggest that the cytoskeleton of the roots is more extended than the cytoskeleton of the leaves (Supplementary data 1).

Conclusively, the inhibitory effect of $\mathrm{CB}, \mathrm{CD}$, and $\mathrm{PH}$ on sucrose and valine uptake in mesophyll and root cells of sugar beet may be exerted through two but not exclusive mechanisms related to the nutrient transport in plant cells (binding to transporters and modification of the cytoskeleton organization). Whatever the mechanism involved, the observed moderate inhibition (not higher than $30 \%$ for sucrose uptake and $50 \%$ for valine) suggests that they do not act as main effectors of nutrient uptake but as modulators in transport processes. A working hypothesis could be that the carrier isoforms evidenced here are not linked in the same way with the actin network in roots and leaves. Thus, a future study should consider the possible involvement of actin-associated proteins in both plant tissues. 
533

534

535

536

537

538

539

540

541

542

543

544

545

546

547

548

549

550

551

\section{Contributions}

PM involved in acquisition of physiological data

PFL Planned the study and involved in acquisition of microscopic data

$\mathrm{AC}$ involved in confocal observations and analyses

$\mathrm{AC}$ involved in bibliographical analysis and critical revision of the manuscript

JMB contributes to obtain fundings and to critical revision of the manuscript

GR involved in analysis and interpretation of the data

All authors wrote the manuscript and approved the final version

\section{Acknowledgments}

The authors are grateful to Dr. Lemoine for his advices and improvement of the manuscript and acknowledge the "Service de Microscopie et d'Imagerie Scientifique (Image UP) of the University of Poitiers, in particular Emile Béré for his help in TEM observations. This work was partly granted by the following 2015-2020 programs: the State-Region Planning Contracts (CPER) and the European Regional Development Fund (FEDER). 
References

553

554

555

556

557

558

559

560

561

562

563

564

565

566

567

568

569

570

571

572

573

574

575

576

577

578

579

Abu-Abied M, Golomb L, Belausov E, Huang S, Geiger B, Kam Z, Staiger CJ, Sadot E (2006) Identification of plant-cytoskeleton-interacting proteins by screening for actin stress fiber association in mammalian fibroblasts. Plant J 48: 367-379

Allen ED, Aiuto R, Sussman AS (1980) Effets of cytochalasins on Neurospora crassa - I. Growth and Ultrastructure. Protoplasma 102: 63-75

Augustin R (2010) The protein family of glucose transport facilitators: it's not only about glucose after all. IUMB life 62: 315-333

Bearden JC (1978) Quantification of submicrogram quantities protein by an improved-dye binding assay. Biochim Biophys Acta 533: 525-529

Bouché-Pillon S, Fleurat-Lessard P, Serrano R, Bonnemain JL (1994) Asymmetric distribution of the plasma-membrane $\mathrm{H}^{+}$-ATPase in embryos of Vicia faba L. with special reference to tranfer cells. Planta 193: 392-397

Bush DR (1989) Proton-coupled sucrose transport in plasmalemma vesicles isolated from sugar beet (Beta vulgaris L. cv Great Western) leaves. Plant Physiol 89: 1318-1323

Bush DR (1990) Electrogenicity, pH-dependence, and stoichiometry of the proton-sucrose symport. Plant Physiol 93: 1590-1593

Carpaneto A, Geiger D, Bamberg E, Sauer N, Fromm J, Hedrich R (2005) Phloem-localized, proton-coupled sucrose carrier ZmSUT1 mediates sucrose efflux under the control of the sucrose gradient and the proton motive force. J Biol Chem 280: 21437-21443

Casella JF, Flanagan MD, Lin S (1980) Cytochalasin D inhibits actin polymerization and induces depolymerization of actin filaments formed during platelet shape change. Nature 293: 302305

Chen L-Q (2014) Sweet sugar transporters for phloem transport and pathogen nutrition. New Phytol. 201: 1150-1155.

Cheung PT, Hammerman MR (1989) Cytochalasin B binding to rabbit proximal tubular basolateral membranes. Kidney Internat 35: 1290-1294

Cooper JA (1987) Effects of cytochalasin and phalloidin on actin. J Cell Biol 105: 1473-1478 
580 581 582 583 584 585 586 587 588 589 590 591 592 593 594 595 596 597 598 599 600 601 602 603 604 605 606 607 608 609

Deeks MJ, Calcutt, JR, Ingle EKS, Hawkings TJ, Chapman S, Richardson AC, Mentlak DA, Dixon MR, Cartwright F, Smertenko AP, Oparka K, Hussey PJ (2012) A superfamily of actinbinding proteins at the actin-membrane Nexus of higher plants. Curr Biol 22: 1595-1600

Delrot S (1981) Proton fluxes associated with sugar uptake in Vicia faba leaf tissues. Plant Physiol 68: 706-711

Delrot S, Despeghel JP, Bonnemain JL (1980) Phloem loading in Vicia faba leaves: effect of nethylmaleimide and parachloromercuribenzenesulfonic acid on $\mathrm{H}^{+}$extrusion, $\mathrm{K}^{+}$and sucrose uptake. Planta 149: 144-148

Diez-Sampedro A., Lostao MP, Barber A (2000) Cytoskeleton involvement on intestinal absorption processes. J Physiol Biochem 56: 25-32

Esau K., Thorsch J (1985) Sieve plate pores and plasmodesmata, the communication channels of the symplast: ultrastructural aspect and developmental relations. Amer J Bot 1: 1641-1653

Estensen RD, Plagemann PG (1972) Cytochalasin B: inhibition of glucose and glucosamine transport. Proc Natl Acad Sci USA 69: 1430-1434

Feuerstein A, Niedermeier M, Bauer K, Engelmann S, Hoth S, Stadler R, Sauer N (2010) Expression of the AtSUC1 gene in the female gametophyte, and ecotype-specific expression differences in male reproductive organs. Plant Biol 12 (Suppl 1): 105-114

Fleurat-Lessard P, Vantard M, Schmit AC, Stoeckel H, Roblin G (1993) Characterization and immunocytochemical distribution of microtubules and F-actin filament in protoplasts of Mimosa pudica motor cells. Plant Physiol Biochem 31: 757-764

Fleurat-Lessard P, Frangne N, Maeshima M, Ratajczak R, Bonnemain JL, Martinoia E (1997) Increased expression of vacuolar aquaporin and $\mathrm{H}^{+}$-ATPase related to motor cell function in Mimosa pudica L. Plant Physiol 114: 827-834

Gahrtz M, Stolz L, Sauer N (1994) A phloem-specific sucrose- $\mathrm{H}^{+}$symporter from Plantago major L. supports the model of apoplastic phloem loading. Plant J 6: 17-23

Gallagher SR, Leonard RT (1982) Effect of vanadate, molybdate and azide on membraneassociated ATPase and soluble phosphatase activities of corn roots. Plant Physiol 70: 13351440

Gallet O, Lemoine R, Delrot, S (1989) The sucrose carrier of the plant plasma membrane. I. Differential affinity labeling. Biochim Biophys Acta 978: 56-64 
610

611

612

613

614

615

616

617

618

619

620

621

622

623

624

625

626

627

628

629

630

631

632

633

634

635

636

637

638

639

640

Gallet O, Lemoine R, Gaillard C, Larsson C, Delrot S (1992) Selective inhibition of active uptake of sucrose into plasma membrane vesicles by polyclonal sera directed against a 42 kilodalton plasma membrane polypeptide. Plant Physiol 98: 17-23

Giaquinta RT (1977) Possible role of $\mathrm{pH}$ gradient and membrane ATPase in the loading of sucrose into the sieve tubes. Nature 267: 369-370

Harada N, Inagaki N (2012) Role of sodium-glucose transporter in glucose uptake oft he intestine and kidney. J Diabetes Invest 3: 352-353

Hardham AR, Jones DA, Takemoto D (2007) Cytoskeleton and cell wall function in penetration resistance. Curr Opin Plant Biol 10: 342-348

Hediger MA, Coady MJ, Ikeda TS, Wright EM (1987) Expression cloning and cDNA sequencing of the $\mathrm{Na}^{+}$/glucose transporter. Nature 330: 379-381

Higaki T, Sano T, Hasezawa S (2007a) Actin microfilament dynamics and actin side-binding proteins in plants. Curr Opinion Plant Biol 10: 549-556

Higaki T, Goh T, Hayashi T, Kutsuna N, Kadota Y, Hasezawa S, Sano T, Kuchitsu K (2007b) Elicitor-induced cytoskeletal rearrangement relates to vacuolar dynamics and execution of cell death: in vivo imaging of hypersensitive cells death in tobacco BY-2 cells. Plant Cell Physiol 48: $1414-1425$

Hussey PJ, Ketelaar T, Deeks MJ (2006) Control of the actin cytoskeleton in plant cell growth. Annu Rev Plant Biol 57: 109-125

Jung CY, Rampal AL (1977) Cytochalasin B binding sites and glucose transport carrier in human erythrocyte ghosts. J Biol Chem 252: 456-5463

Jung B, Ludewig F, Schulz A, Meißner G, Wöstefeld N, Flügge U-I, Pommerrenig B, Wirsching P, Sauer N, Koch W, Sommer F, Mühlhaus T, Schroda M, Cuin TA, Graus D, Marten I, Hedrich R, Neuhaus KE (2015) Identification of the transporter responsible for sucrose accumulation in sugar beet taproots. Nature Plants 1: 14001

Kandasamy M, Meagher RB (1999) Actin-organelle interaction: association with chloroplast in Arabidopsis leaf mesophyll cells. Cell Motil Cytoskeleton 44, 110-118

Kellett GL, Brot-Laroche E, Mace OJ, Leturque A (2008) Sugar absorption in the intestine: the role of GLUT2. Annu Rev Nutrition 28: 35-54

Kijima ST, Hirose K, Kong S-G, Wada M, Uyeda TQP (2016) Distinct biochemical properties of Arabidopsis thaliana actin isoforms. Plant Cell Physiol 57: 46-56 
Krügel U, Veenhoff LM, Langbein J, Wiederhold E, Liesche J, Friedrich T, Grimm B, Martinoia 642 E, Poolman B, Kühn (2008) Transport and sorting of the Solanum tuberosum sucrose transporter SUT1 is affected by posttranslational modification. Plant Cell 20: 2497-2513

644

645

Krupka RM, Devés R (1980) Testing transport systems for competition between pairs of reversible inhibitors. J Biol Chem $255: 11870-11874$

646

Lachaud S (1964) La croissance en épaisseur de l'hypocotyle de Beta vulgaris L. et les modifications que peut y provoquer l'acide gibbérellique. C R Séanc Soc Biol 158: 348-350

648

649

Laemmli UK (1970) Cleavage of structural proteins during the assembly of the head of bacteriophage T4. Nature 227: 680-685

650

651

Laurel AM, Lucas WJ (1996) Plasmodesmal cell-to-cell transport of proteins and nucleic acids. Plant Molec Biol 32: 251-273

652

Leigh RA, Rees T, Fuller WA, Banfield J (1979) The location of acid invertase activity and sucrose in the vacuole of storage roots of beetroot (Beta vulgaris). Biochem J 178: 539-547.

654

Leitch JM, Carruthers A (2009) $\alpha$ - and $\beta$-monosaccharide transport in human erythrocytes. Amer 655 J. Physio. Cell Physiol 296: C151-C161

656

657

Lemoine R (2000) Sucrose transporters in plants: update on function and structure. Biochim Biophys Acta 1465: 246-262

658

Lemoine R, Delrot S (1987) Recognition of phlorizin by the carriers of sucrose and hexose in broad bean leaves. Physiol Plant 69: 639-644

Lemoine R, Delrot S (1989) Proton motive force-driven sucrose uptake in sugar beet plasma membrane vesicles. FEBS Lett 249: 129-133

Lemoine R, Bourquin S, Delrot S (1991) Active uptake of sucrose by plant PMV: determination of some important physical and energetical parameters. Physiol Plant 82: 377-384

Lemoine R, Kühn C, Thiele N, Delrot S, Frommer WB (1996) Antisense inhibition of the sucrose transporter: effect on amount of carrier and sucrose transport activity. Plant Cell Environ 19: $1124-1131$

Li ZS, Noubahni AM, Bourbouloux A, Delrot S (1994) Affinity purification of sucrose binding protein from the plant plasma membrane. Biochim Biophys Acta 1219: 389-397

Lin S, Lin DC, Flanagan MD (1978) Specificity of the effects of cytochalasin B on transport and 669 motile processes. Proc Natl Acad Sci USA 75: 329-333 
671

672

673

674

675

676

677

678

679

680

681

682

683

684

685

686

687

688

689

690

691

692

693

694

695

696

697

698

699

700

701
Lopez A, de Bony J, Dupou-Cezanne L, Tournier JF, Schram V, Welby M, Tocanne JF (1994) Organisation latérale, dynamique translationnelle et percolation dans les membranes biologiques. De la matière du vivant. Les systèmes moléculaires organisés. CNRS-Images de la Recherche 2: 103-106

Lucas WJ, Ding B, Van Der Schoot C (1993) Plasmodesmata and the supracellular nature of plants. New Phytol 125: 435-476

Marrè E (1979) Fusicoccin: a tool in plant physiology. Annu Rev Plant Physiol 30: 273-288

Martinière A, Gayral P, Hawes C, Runions J (2011) Building bridges: formin1 of Arabidopsis forms a connection between the cell wall and the actin cytoskeleton. Plant J 66: 354-365

McLean BG, Eubanks S, Meagher R (1990) Tissue specific expression of divergent actins in soybean root. Plant Cell 2: 335-344

Michaud D, Guillet G, Rogers PA, Charest PM (1991) Identification of a $220 \mathrm{kDa}$ membraneassociated plant cell protein immunologically related to human $\beta$-spectrin. FEBS Lett 294: 77 80

Michonneau P, Roblin G, Bonmort J, Fleurat-Lessard P (2004) Valine uptake in the tap root of sugar beet: a comparative analysis with sucrose uptake. J Plant Physiol. 161: 1299-1314

Mizel SB, Wilson L (1972) Inhibition of the transport of several hexoses in mammalian cells by cytochalasin B. J Biol Chem 247: 4102-4105

Mueckler M, Caruso C, Baldwin SA, Panico M, Blench I, Morris HR, Allard WJ, Lienhard GE, Lodish HF (1985) Sequence and structure of a human glucose transporter. Science 229: 941945

Nieberl P, Ehrl C, Pommerrenig B, Graus D, Marten I, Jung B, Ludewig F, Koch W, Harms K, Flügge U-I, Neuhaus HE, Hedrich R, Sauer N (2017) Functional characterization and cell specificity of BvSUT1, the transporter that loads sucrose into the phloem of sugar beet (Beta vulgaris L.) source leaves. Plant Biol 19, 315-326

Noubahni AM, Sakr S, Denis MH, Delrot S (1996) Transcriptional and post-transcriptional control of the plasma membrane $\mathrm{H}^{+}$-ATPase by mechanical treatments. Biochim Biophys Acta 1281: 213-219

O'Neill SD, Spanswick RM (1984) Effects of vanadate on the plasma membrane ATPase of red beet and corn. Plant Physiol 75: 586-591 
702 703 704 705 706 707 708 709 710 711

712

713

714

715

716

717

718

719

720

721

722

723

724

725

726

727

728

729

730

731

Pappenheimer JR, Reiss KZ (1987) Contribution of solvent drag through intracellular junctions to absorption of nutrients by the small intestine of the rat. J Membr Biol 100: 123-126

Parthasarathy MV, Perdue TD, Witztum A, Alvernaz J (1985) Actin network as a normal component of the cytoskeleton in many vascular plant cells. Amer J Bot 72: 1318-1323

Pollard TD, Borisy GG(2003) Cellular motility driven by assembly and disassembly of actin filaments. Cell 112: 453-465

Rampal AL, Pinkovsky HB, Jung CY (1980) Structure of cytochalasins and cytochalasin B binding sites in human erythrocyte membranes. Biochemistry 19: 679-683

Riesmeier JW, Willmitzer L, Frommer WB (1992) Isolation and characterization of a sucrose carrier cDNA from spinach by functional expression in yeast. EMBO J 11: 4705-4713

Sakr S, Lemoine R, Gaillard C, Delrot S (1993) Effect of cutting on solute uptake by plasma membrane vesicles from sugar beet (Beta vulgaris L.) leaves. Plant Physiol 103: 49-58

Sakr S, Noubahni M, Bourbouloux A, Riesmeier J, Frommer WB, Sauer N, Delrot S (1997) Cutting, ageing and expression of plant membrane transporters. Biochim Biophys Acta 1330: 207-216

Sauer N (2007) Molecular physiology of higher plant sucrose transporters. FEBS Lett 581: 23092317

Sauer N, Stolz J (1994) SUC1 and SUC2: two sucrose transporters from Arabidopsis thaliana; expression and characterization in baker's yeast and identification of the histidine-tagged protein. Plant J 6: 67-77

Schmit AC, Lambert AM (1988) Plant actin filament and microtubule interactions during anaphase-telophase transition: effects of antagonist drugs. Biol Cell 64: 309-319

Serrano R (1989) Structure and function of plasma membrane ATPase. Annu Rev Plant Physiol Plant Molec Biol 40: 61-84

Silverman M, Turner RJ (1982) 2-deoxy-D-glucose transport in dog kidney. Amer J Physiol 242: F711-720

Sivitz AB, Reinders A, Ward JM (2008) Arabidopsis sucrose transporter AtSUC1 is important for pollen germination and sucrose-induced anthocyanin accumulation. Plant Physiol 147: $92-$ 100

Snyder FW, Carlson GE (1978) Photosynthate partitioning in sugar beet. Crop Sci 18: 657-669 
Staiger CJ, Schliwa M (1987) Actin localisation and function in higher plants. Protoplasma 141: $1-12$

Sze H (1985) $\mathrm{H}^{+}$-translocating ATPases: advances using membrane vesicles. Annu Rev Plant Physiol 36: 175-198

Tian M, Chaudry F, Ruzicka DR, Meagher RB, Staiger CJ, Ray B (2009) Arabidopsis actindepolymerizing factor AtADF4 mediates defense signal transduction triggered by the Pseudomonas syringae effector AvrPphB. Plant Physiol 150: 815-824

Towbin H, Staehelin T, Gordon J (1979) Electrophoretic transfer of protein from polyacrylamide gels to nitrocellulose sheets: procedure and some applications. Proc Natl Acad Sci USA 76: $4350-4354$

Tsakiridis T, Vranic M, Klip A (1994) Disassembly of the actin network inhibits insulindependent stimulation of glucose transport and prevents recruitment of glucose transporters to the plasma membrane. J Biol Chem 269: 29934-29942

Uezato T, Fujita M (1986) Cytochalasin B-binding proteins related to glucose transport across the basolateral membrane of the intestinal epithelial cell. J Cell Sci 85: 177-185

Van Bel AJE, Gamalei Y (1991) Multiprogrammed phloem loading. In: Bonnemain, JL, Delrot S, Lucas WJ, Dainty J (eds), Recent advances in phloem transport and assimilate compartimentation, Ouest Editions, Presses Académiques, Nantes, pp. 128-139

Van Bel AJE, Kempers R (1990) Symplastic isolation of the sieve element-companion cell complex in the phloem of Ricinus communis and Salix alba stems. Planta 183: 69-76

Van Gestel K, Köhler RH, Verbelen J-P (2002) Plant mitochondria move on F-actin, but their positioning in the cortical cytoplasm depends on both F-actin and microtubules. J Exp Bot 53: 659-667

Vaughn MW, Harrington GN, Bush DR (2002) Sucrose-mediated transcriptional regulation of sucrose symporter activity in the phloem. Proc Natl Acad Sci USA 99: 10876-10880

Williamson RE (1979) Actin in motile and other processes in plants cells. Can J Bot 58: 766-772

Wright EM, Loo DDF, Hirayama BA (2011) Biology of human sodium glucose transporters. Physiol Rev 91: 733-794

Wyse RE, Zamski E, Deri Tomos A (1986) Turgor regulation of sucrose transport in sugar beet taproot tissues. Plant Physiol 81: 478-481 
Zhang JZ, Ismail-Beigi F (1998) Activation of Glu1 transporter in human erythrocytes. Arch Biochem Biophys 356: 86-92

764

Zigmond SH, Hirsh JG (1972) Cytochalasin B inhibition of D-2-deoxyglucose transport into 765 leukocytes and fibroblasts. Science 176: 1432-1434 


\section{Legends of the figures}

Figure 1. (A) The Beta vulgaris plants used in the present study at early developmental stage (120 days) showing a $2 \mathrm{~cm}$-wide root and seven exporting leaves. (B) Autoradiography of a root disc quarter showing the distribution of radioactive ${ }^{14} \mathrm{C}$ [sucrose], in the vascular bundles (VB, strong white labeling) and in the storage cell area (SC, faint white labeling) after 1 hour absorption. (C) Cross-section of the vascular bundle area of the root concentric rings showing the xylem vessels (XV) surrounded by xylem parenchyma (XP), cambium with aligned cells (C), phloem tissue $(\mathrm{PH})$ and the adjacent storage area with wide SCs. (D, D') Detail in transmission electron microscopy (TEM) of SCs showing a large vacuole (V) pressing the thin cytoplasm (arrow) and nucleus (N) against the wall (W). (E) Autoradiography of a leaf disc showing the distribution of radioactive ${ }^{14} \mathrm{C}$ [sucrose], in the mesophyll veins (arrow, strong white labeling) and in adjacent parenchyma (faint white labelling) after 1 hour absorption. (F) Cross-section of a small leaf vein: xylem and phloem tissues surrounded by the bundle sheath (BS) are surrounded by the large mesophyll cells (M), (G) TEM of the longitudinal section of a palisade mesophyll cell containing many plastids (P), a wide nucleus and large vacuoles. Paraformaldehyde/Glutaraldehyde $/ \mathrm{OsO}_{4} / \mathrm{LRWhite.} \mathrm{(C,} \mathrm{F)} \mathrm{Semi} \mathrm{thin} \mathrm{sections,} \mathrm{toluidine} \mathrm{blue}$ staining, Zeiss Axioplan; (D, G) Ultrathin sections, uranyl/lead, TEM, Jeol 1010. Bars: (A) $1 \mathrm{~cm}$, (B, E) $1 \mathrm{~mm},(\mathbf{C}, \mathbf{D}, \mathbf{F}, \mathbf{G}) 20 \mu \mathrm{m},\left(\mathbf{D}^{\prime}\right) 30 \mu \mathrm{m}$.

Figure 2. Western blot analysis of protein extracted from plasma membrane vesicles $(10.5 \mu \mathrm{g} / \mu 1$ of proteins) isolated from the root and leaf of Beta vulgaris. Immunoblotting with 1/200 anti-actin antibody reveals a band corresponding to an actin isoform at $42 \mathrm{kDa}$ strongly labeled in the root but weakly in the leaf. Immunoblotting with 1/2000 diluted anti-AtSUC1 antibody reveals a 42 $\mathrm{kDa}$ isoform strongly labeled in the root but weakly in the leaf. Note that two other bands at 46 $\mathrm{kDa}$ (low labeling) and at $56 \mathrm{kDa}$ (strong labeling) were also observed in the root extract. Control, purified actin. Western blot by ECL kit (ref: RPN 2109).

Figure 3. Immunogold labeling of F-actin $(\mathbf{A}, \mathbf{D})$ and $\operatorname{AtSUC1}(\mathbf{B}, \mathbf{E})$ on plasma membrane vesicles (diameter $0.4-0.8 \mu \mathrm{m}$ ) purified from roots $(\mathbf{A}, \mathbf{B}, \mathbf{C})$ and leaves $(\mathbf{D}, \mathbf{E}, \mathbf{F})$ of sugar beet. Controls (C, F) obtained by primary antibody omission. Paraformaldehyde/Glutaraldehyde/OsO $\mathrm{O}_{4} / \mathrm{LRWhite.} \mathrm{Ultrathin} \mathrm{sections} \mathrm{in} \mathrm{transmission} \mathrm{electron}$ microscopy. Labeling by gold particles (15 nm diameter) indicated by arrows. Bars $=0.5 \mu \mathrm{m}$.

Figure 4. Detail of immunogold labeling (arrows) of actin (1/20 diluted ICN anti-actin) (A, D) and AtSUC1 (1/40 diluted) (B, E) and control by antibody omission (C, F) in root storage cells (A, B, C) and mesophyll cells (D, E, F) of sugar beet. V, vacuole; W, wall. Paraformaldehyde/Glutaraldehyde/OsO 4 , LRWhite. Site recognition by $15 \mathrm{~nm}$ diameter gold particles in transmission electron microscopy. Bars $=0.5 \mu \mathrm{m}$. 
Figure 5. (A) Protoplast of storage cells in the tap root. (B) Red labeling of F-actin with

805

806

807

808

809

810

811

812

813

814

815

816

817

818

819

820

821

822

823

824

825

826

827

828

829

830 rhodamine phalloidin (C) Immunolabeling of AtSUC1 in the plasma membrane (green by fluorescein isothiocyanate (FITC) detection), using 1/40 diluted antibody. (D) Co-labelling of Factin and AtSUC1. (E) Control: antibody and rhodamine omission. (F) Protoplast of mesophyll cells containing many plastids (blue-green colored). (G) Red labeling of F-actin with rhodamine phalloidin. (H) Immunolabeling of AtSUC1 in the plasma membrane (green by FITC detection) using 1/40 diluted antibody. (I) Co-labeling of F-actin and AtSUC1. (J) Control: antibody and rhodamine omission. Paraformaldehyde/Glutaraldehyde. Zeiss Axioplan (A, F), Olympus confocal microscopy (B-E, G-J). Bars $=20 \mu \mathrm{m}$.

Figure 6. Immuno-colabeling of AtSUC1 (gold particles of $10 \mathrm{~nm}$ diameter) and actin (gold particles of $5 \mathrm{~nm}$ diameter) performed on ultrathin sections of plasma membrane vesicles (ve) obtained from Beta vulgaris roots (A) and leaves (B), and in ultrathin sections of root parenchyma (D) and mesophyll cells (E). Recognized sites of both proteins are distributed along plasma membrane area but absent along the tonoplast. Plasma membrane and tonoplast are respectively indicated by black- and white dotted lines in absence of uranyl/lead contrast. cyt, cytoplasm; V, vacuole; W, wall. C: control: absence of labeling in plasma membrane vesicles when antibodies

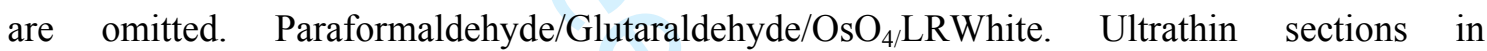
transmission electron microscopy. Bars $=50 \mathrm{~nm}$.

Figure 7. Uptake of $1 \mathrm{mM}$ sucrose $(\mathbf{A}, \mathbf{B})$ and $1 \mathrm{mM}$ valine $(\mathbf{C}, \mathbf{D})$ by discs harvested from storage root tissues $(\mathbf{A}, \mathbf{C})$ and leaf tissues $(\mathbf{B}, \mathbf{D})$ of sugar beet. Uptake (30 min. duration) was measured after the various time duration at $10 \mu \mathrm{M}$ final concentration of cytochalasin $\mathrm{B}(\mathrm{CB})$, cytochalasin $\mathrm{D}(\mathrm{CD})$ and phalloidin $(\mathrm{PH})$. Mean $\pm \mathrm{SE} ; \mathrm{n}=45$ from three independent experiments.

Figure 8. Inhibition of the uptake of $1 \mathrm{mM}$ sucrose $(\mathbf{A}, \mathbf{C})$ and $1 \mathrm{mM}$ valine $(\mathbf{B}, \mathbf{D})$ in the root (white bars) and leaf (dark bars) tissues of sugar beet treated for $12 \mathrm{~h}$ with various concentrations of $\mathrm{CB}(\mathbf{A}, \mathbf{B})$ and $\mathrm{CD}(\mathbf{C}, \mathbf{D})$. Mean $\pm \mathrm{SE} ; \mathrm{n}=45$ from three independent experiments. Uptake duration: $30 \mathrm{~min}$;

Figure 9. Effect of cytochalasin B (CB), cytochalasin D (CD) and phalloidin (PH) applied at 10 $\mu \mathrm{M}$ final concentration on the uptake of $1 \mathrm{mM}$ sucrose $(\mathbf{A}, \mathbf{B})$ and $1 \mathrm{mM}$ valine $(\mathbf{C}, \mathbf{D})$ by PMVs purified from $\operatorname{root}(\mathbf{A}, \mathbf{C})$ and leaf tissues $(\mathbf{B}, \mathbf{D})$.Uptake duration: 3 min. Co: control. Mean \pm SD; $\mathrm{n}=6$ independent experiments. Values given at the top of the bars represent the induced inhibition $(\%)$. 
849

850

851

852

853

854

855

856

857

858

859

860

861

862

863

864

865

866

867

868

869

870

871

Table 1: Effects of cytochalasin B (CB), cytochalasin D (CD) and phalloidin (PH) on proton pumping and vanadate-sensitive ATPase activity of plasma membrane vesicle (PMVs) purified from roots and leaves of Beta vulgaris. n: number of measurements from three independent PMV preparations. Mean \pm SD. *, significantly different from the control at $\mathrm{P}=0.95$ with the StudentFisher $t$ test.

Proton pumping (OD units mg protein ${ }^{-1} \mathrm{~min}^{-1}$ ) in PMVs purified from roots

$\begin{array}{ccccc} & \mathbf{n} & \mathbf{C B} & \mathbf{C D} & \mathbf{P H} \\ \text { Control } & 12 & 0.576 \pm 0.088 & & \\ 1 \mu \mathrm{M} & 6 & 0.600 \pm 0.087 & 0.568 \pm 0.032 & 0.552 \pm 0.088 \\ 10 \mu \mathrm{M} & 6 & 0.552 \pm 0.024 & 0.560 \pm 0.072 & 0.554 \pm 0.104 \\ 50 \mu \mathrm{M} & 6 & 0.408 \pm 0.024^{*} & 0.410 \pm 0.080^{*} & 0.240 \pm 0.016^{*}\end{array}$

Proton pumping (OD units $\mathrm{mg}_{\text {protein }}{ }^{-1} \mathrm{~min}^{-1}$ ) in PMVs purified from leaves $\begin{array}{llll}n & \text { CB } & \text { CD } & \text { PH }\end{array}$

Control $12 \quad 0.373 \pm 0.020$

$\begin{array}{cccll}1 \mu \mathrm{M} & 6 & 0.377 \pm 0.024 & 0.342 \pm 0.008 & 0.334 \pm 0.061 \\ 10 \mu \mathrm{M} & 6 & 0.360 \pm 0.023 & 0.390 \pm 0.060 & 0.412 \pm 0.043 \\ 50 \mu \mathrm{M} & 6 & 0.260 \pm 0.024^{*} & 0.277 \pm 0.080^{*} & 0.282 \pm 0.022^{*}\end{array}$

ATPase activity (nmol Pi mg protein $\left.{ }^{-1} \mathrm{~min}^{-1}\right)$ in PMVs purified from roots $\begin{array}{llll}n & \text { CB } & \text { CD } & \text { PH }\end{array}$ Control $12 \quad 391 \pm 56$

$\begin{array}{ccccc}1 \mu \mathrm{M} & 8 & 437 \pm 55 & 467 \pm 96 & 425 \pm 62 \\ 10 \mu \mathrm{M} & 6 & 430 \pm 30 & 405 \pm 30 & 401 \pm 36 \\ 50 \mu \mathrm{M} & 6 & 293 \pm 52^{*} & 315 \pm 27^{*} & 326 \pm 35^{*}\end{array}$

ATPase activity (nmol Pi mg protein $\left.{ }^{-1} \mathrm{~min}^{-1}\right)$ in PMVs purified from leaves $\begin{array}{llll}n & \text { CB } & \text { CD } & \text { PH }\end{array}$

$\begin{array}{ccccc}\text { Control } & 18 & 597 \pm 61 & & \\ 1 \mu \mathrm{M} & 8 & 588 \pm 104 & 589 \pm 39 & 585 \pm 15 \\ 10 \mu \mathrm{M} & 6 & 531 \pm 57 & 570 \pm 68 & 642 \pm 105 \\ 50 \mu \mathrm{M} & 6 & 328 \pm 70^{*} & 460 \pm 50^{*} & 464 \pm 35^{*}\end{array}$


Table 1: Effects of cytochalasin B (CB), cytochalasin D (CD) and phalloidin $\mathrm{PH})$ on proton pumping and vanadate-sensitive ATPase activity of plasma membrane vesicles (PMVs) purified from roots and leaves of Beta vulgaris. n: number of measurements from three independent PMV preparations. Mean $\pm \mathrm{SD} .{ }^{*}$, significantly different from the control at $\mathrm{P}=0.95$ with the StudentFisher $t$ test.

\begin{tabular}{|c|c|c|c|c|}
\hline \multicolumn{5}{|c|}{ Proton pumping (OD units mg protein-1 $\mathrm{min}^{-1}$ ) in PMVs purified from roots } \\
\hline & $\mathbf{n}$ & CB & CD & PH \\
\hline Control & 12 & $0.576 \pm 0.088$ & & \\
\hline $1 \mu \mathrm{M}$ & 6 & $0.600 \pm 0.087$ & $0.568 \pm 0.032$ & $0.552 \pm 0.088$ \\
\hline $10 \mu \mathrm{M}$ & 6 & $0.552 \pm 0.024$ & $0.560 \pm 0.072$ & $0.554 \pm 0.104$ \\
\hline $50 \mu \mathrm{M}$ & 6 & $0.408 \pm 0.024 *$ & $0.410 \pm 0.080^{*}$ & $0.240 \pm 0.016$ \\
\hline
\end{tabular}

Proton pumping (OD units $\mathrm{mg}$ protein ${ }^{-1} \mathrm{~min}^{-1}$ ) in PMVs purified from leaves

$\begin{array}{cllll}\text { Control } & 12 & 0.373 \pm 0.020 & & \\ 1 \mu \mathrm{M} & 6 & 0.377 \pm 0.024 & 0.342 \pm 0.008 & 0.334 \pm 0.061 \\ 10 \mu \mathrm{M} & 6 & 0.360 \pm 0.023 & 0.390 \pm 0.060 & 0.412 \pm 0.043 \\ 50 \mu \mathrm{M} & 6 & 0.260 \pm 0.024 * & 0.277 \pm 0.080 * & 0.282 \pm 0.022^{*}\end{array}$

ATPase activity (nmol Pi mg protein ${ }^{-1}$ min $\left.^{-1}\right)$ in PMVs purified from roots

n $\quad$ CB $\quad$ CD $\quad$ PH

$\begin{array}{ccccc}\text { Control } & 12 & 391 \pm 56 & & \\ 1 \mu \mathrm{M} & 8 & 437 \pm 55 & 467 \pm 96 & 425 \pm 62 \\ 10 \mu \mathrm{M} & 6 & 430 \pm 30 & 405 \pm 30 & 401 \pm 36 \\ 50 \mu \mathrm{M} & 6 & 293 \pm 52^{*} & 315 \pm 27^{*} & 326 \pm 35^{*}\end{array}$

ATPase activity (nmol Pi mg protein ${ }^{-1}$ min $\left.^{-1}\right)$ in PMVs purified from leaves

$\begin{array}{llll}n & \text { CB } & \text { CD } & \text { PH }\end{array}$

$\begin{array}{ccccc}\text { Control } & 18 & 597 \pm 61 & & \\ 1 \mu \mathrm{M} & 8 & 588 \pm 104 & 589 \pm 39 & 585 \pm 15 \\ 10 \mu \mathrm{M} & 6 & 531 \pm 57 & 570 \pm 68 & 642 \pm 105 \\ 50 \mu \mathrm{M} & 6 & 328 \pm 70^{*} & 460 \pm 50^{*} & 464 \pm 35^{*}\end{array}$




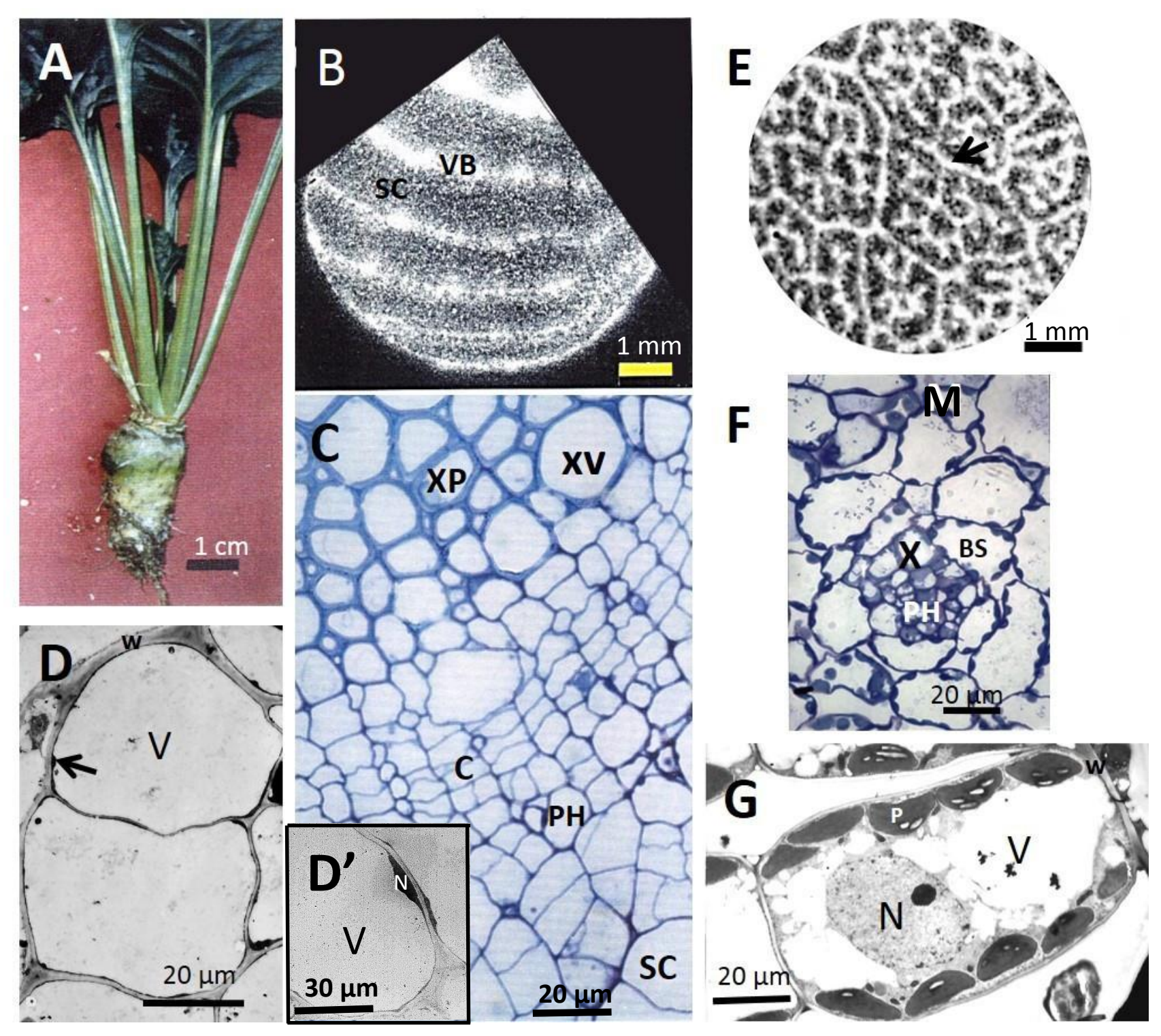

Figure 1 
Figure 2

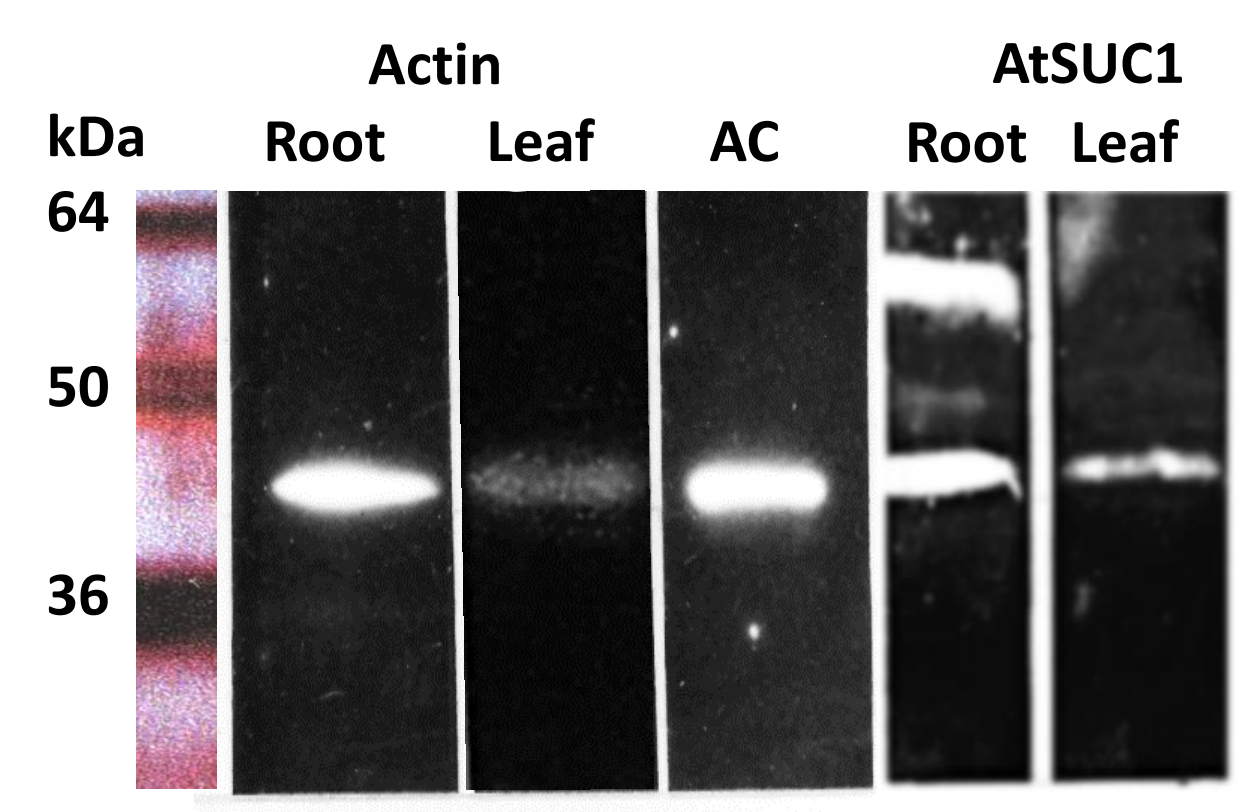



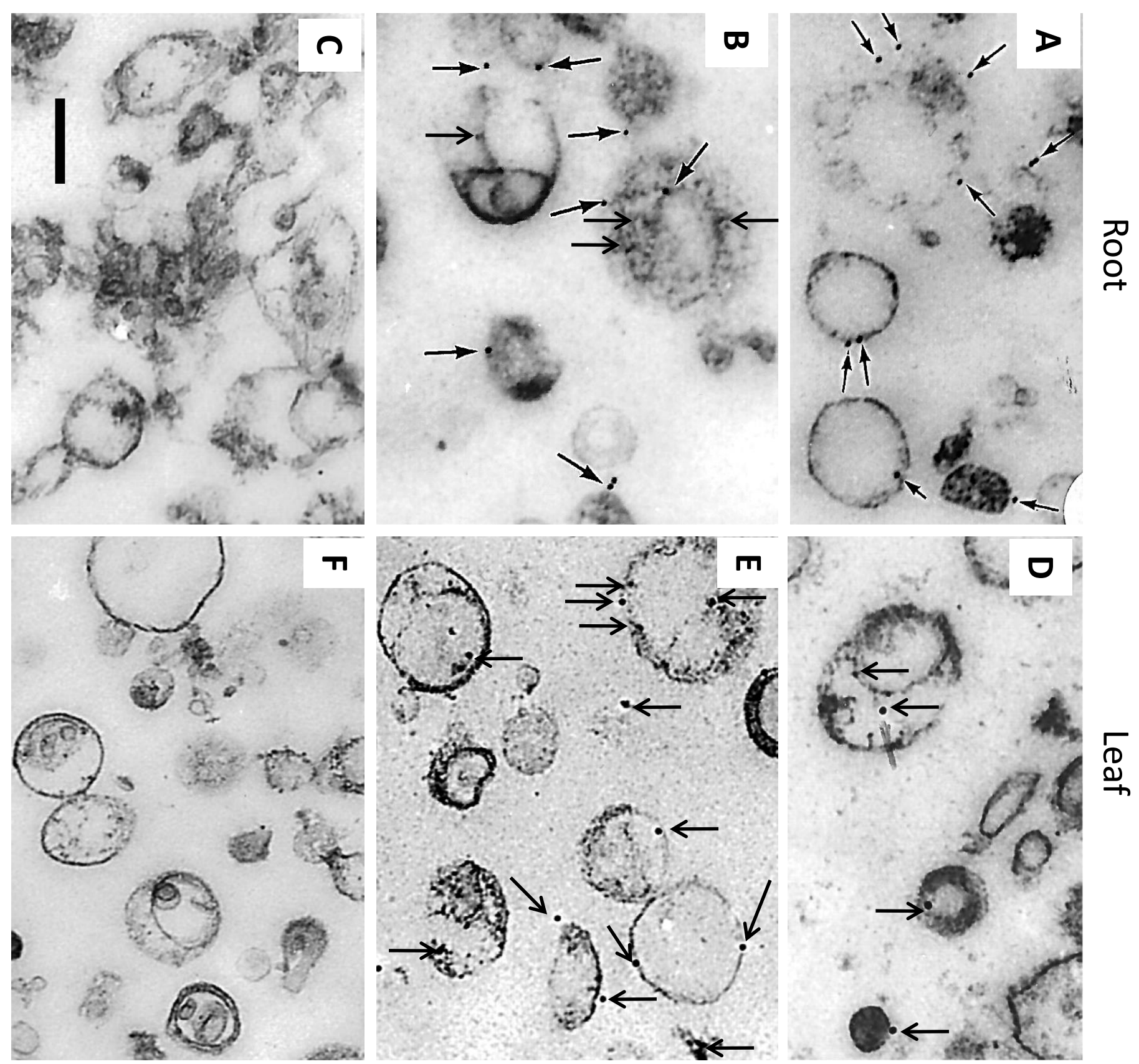

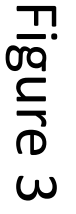


Figure 4

ROOT
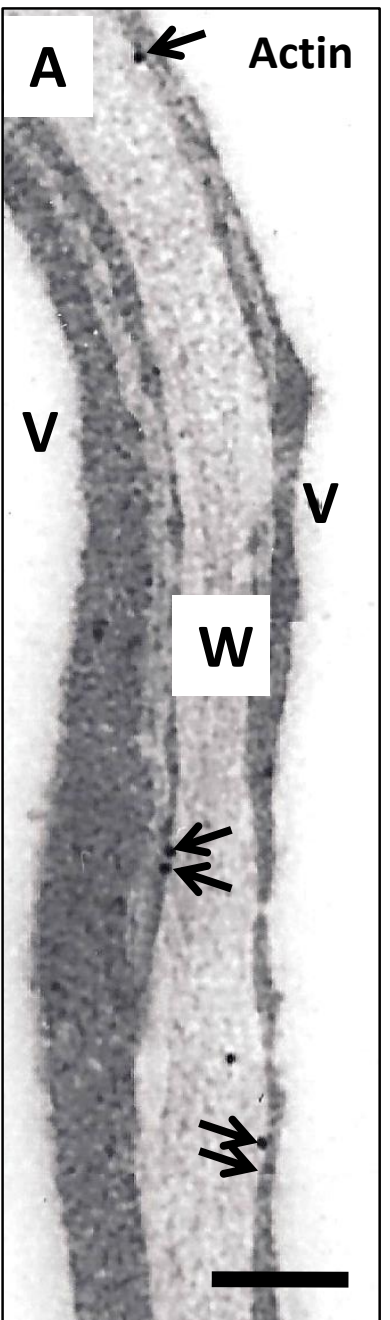
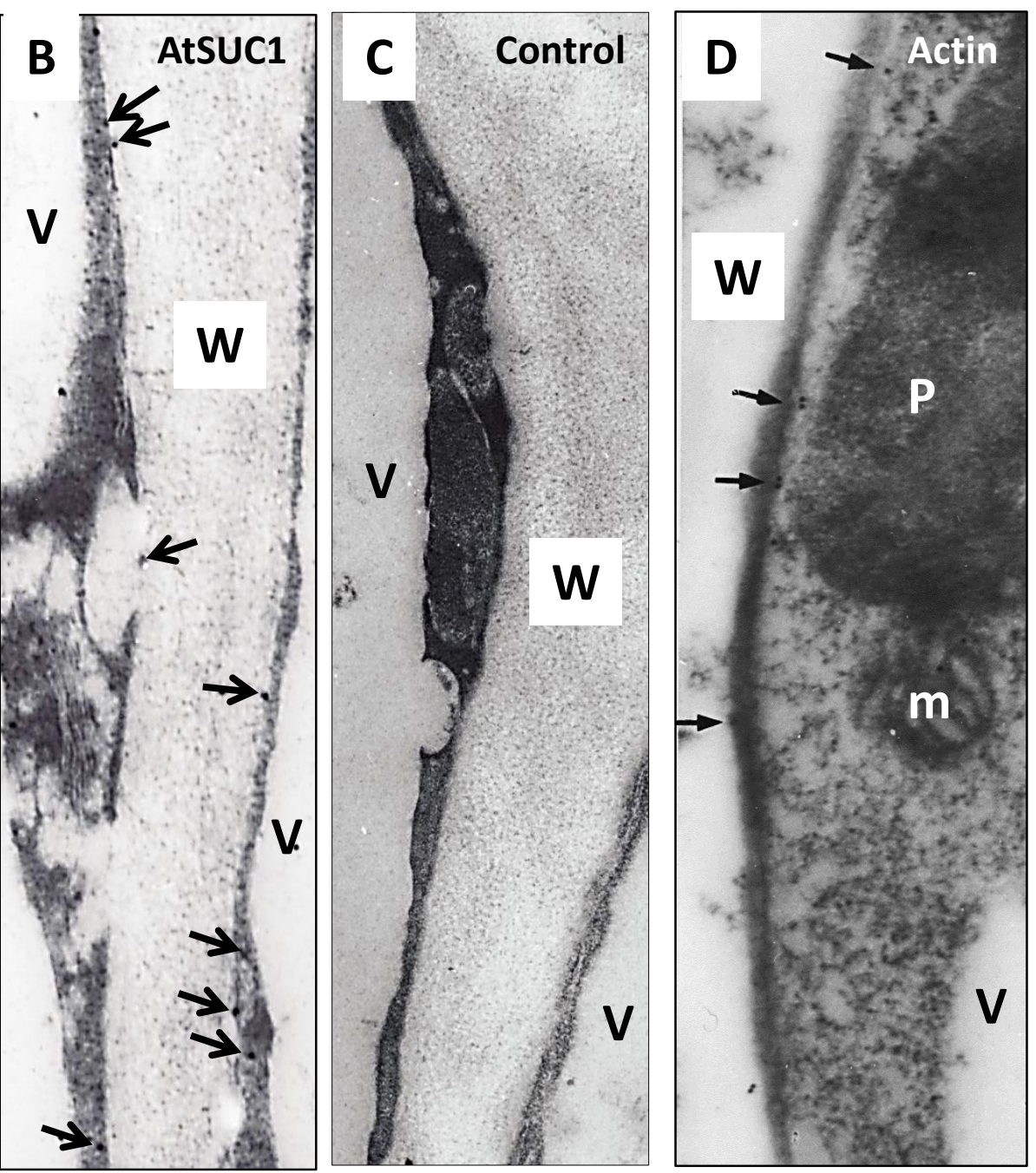

LEAF

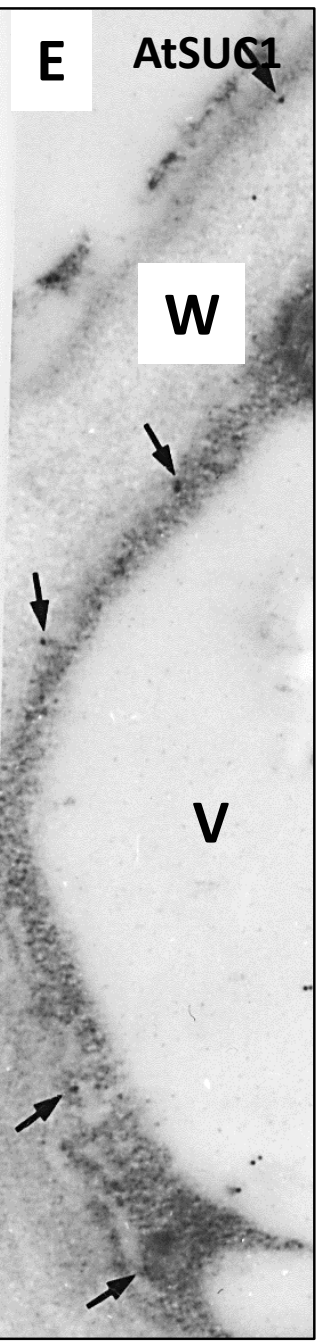

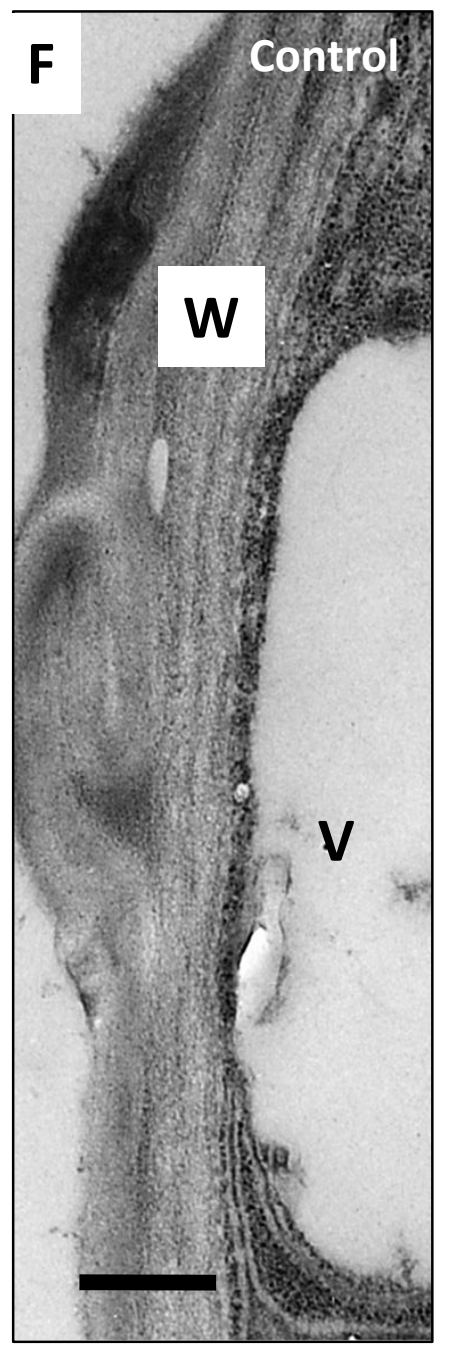


Figure 5

Protoplast of root

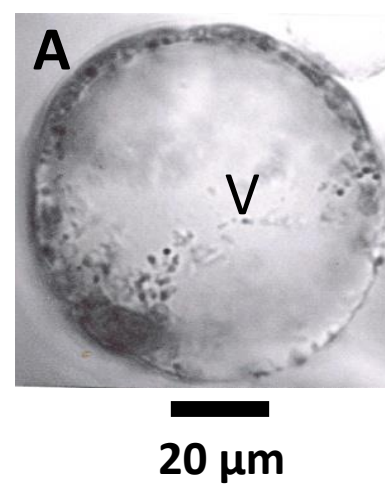

Protoplast of leaf

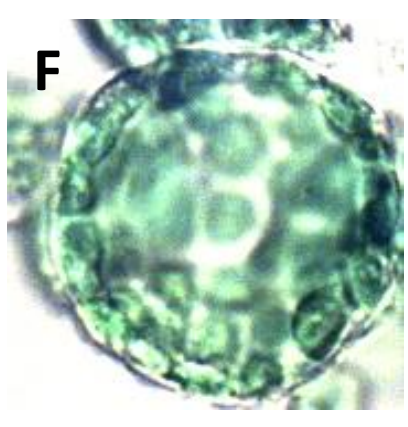

Actin-RhodaminePhalloidin
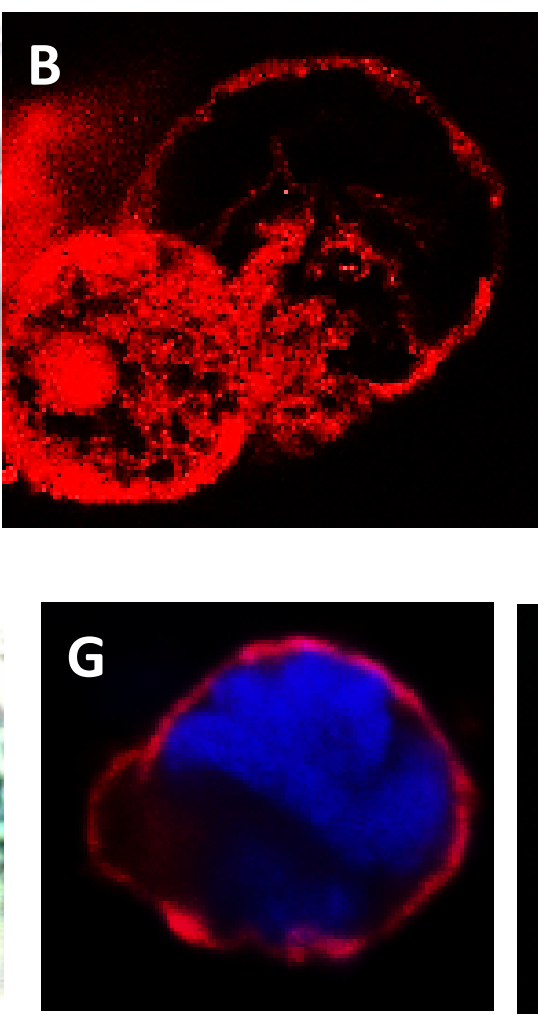

AtSUC1-immuno FITC
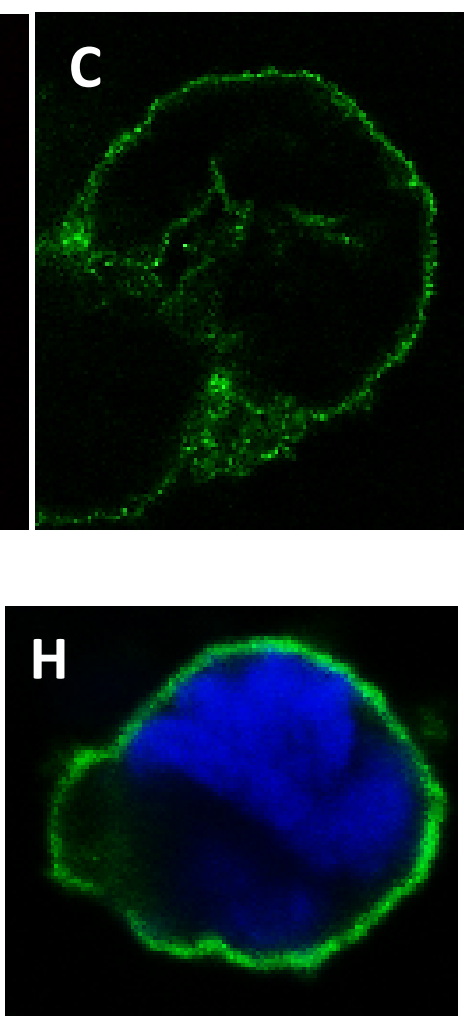

merge
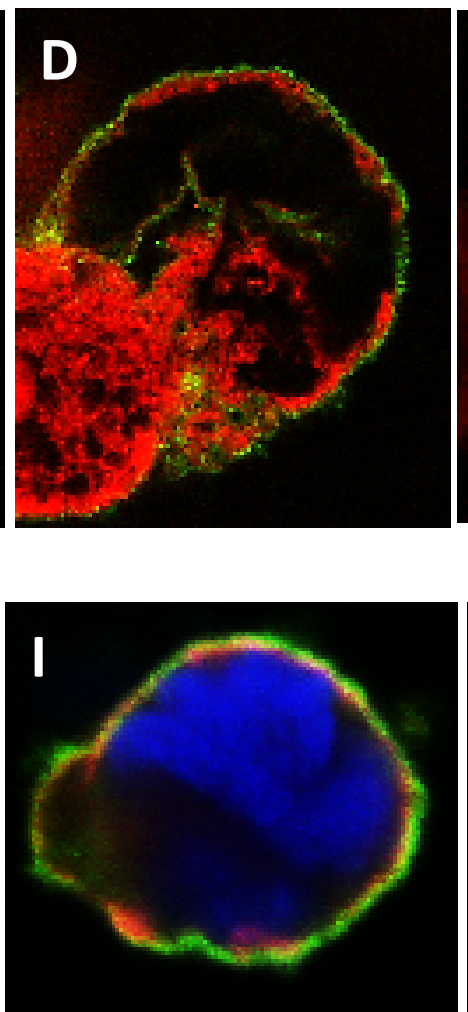

E

J 
Figure 6

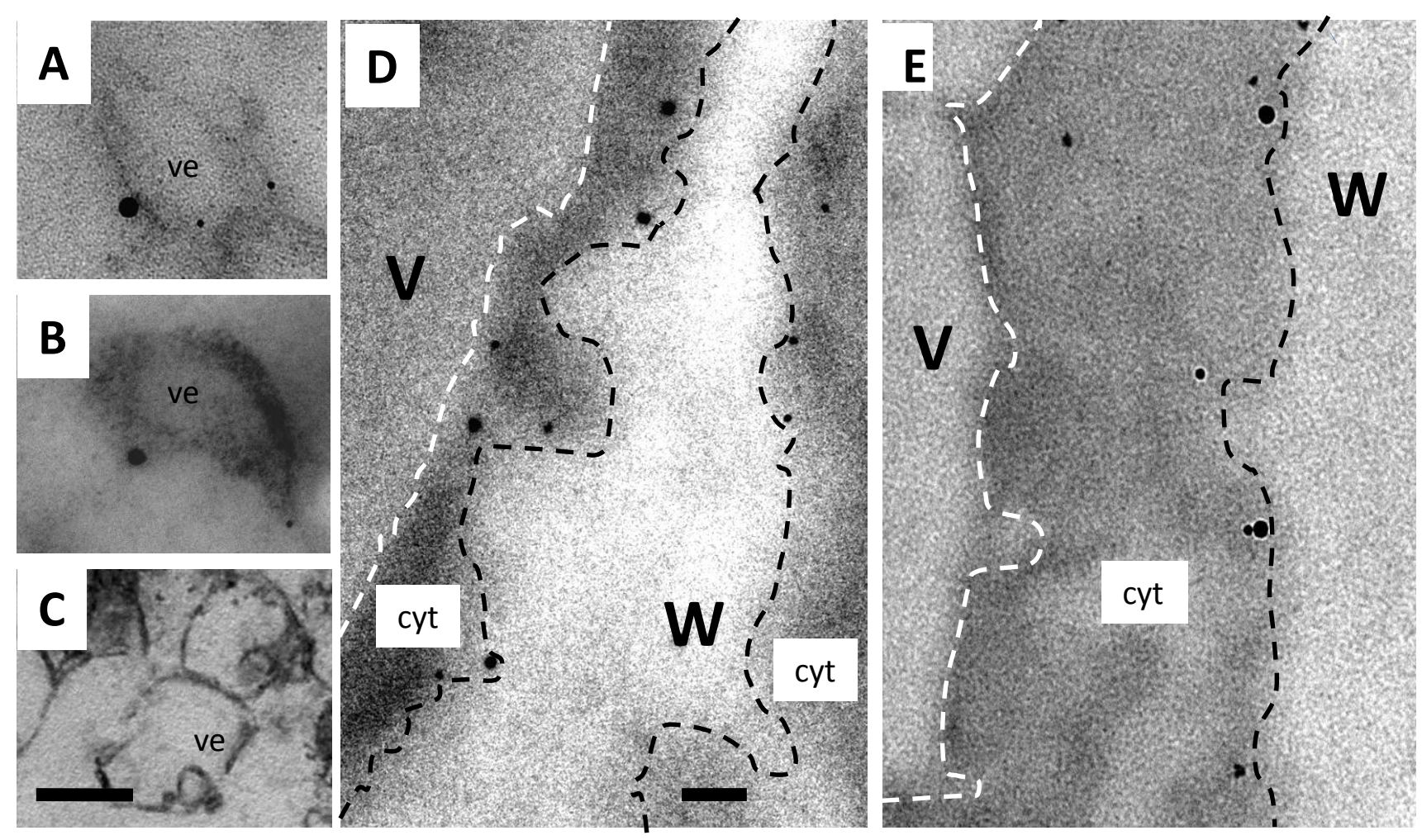



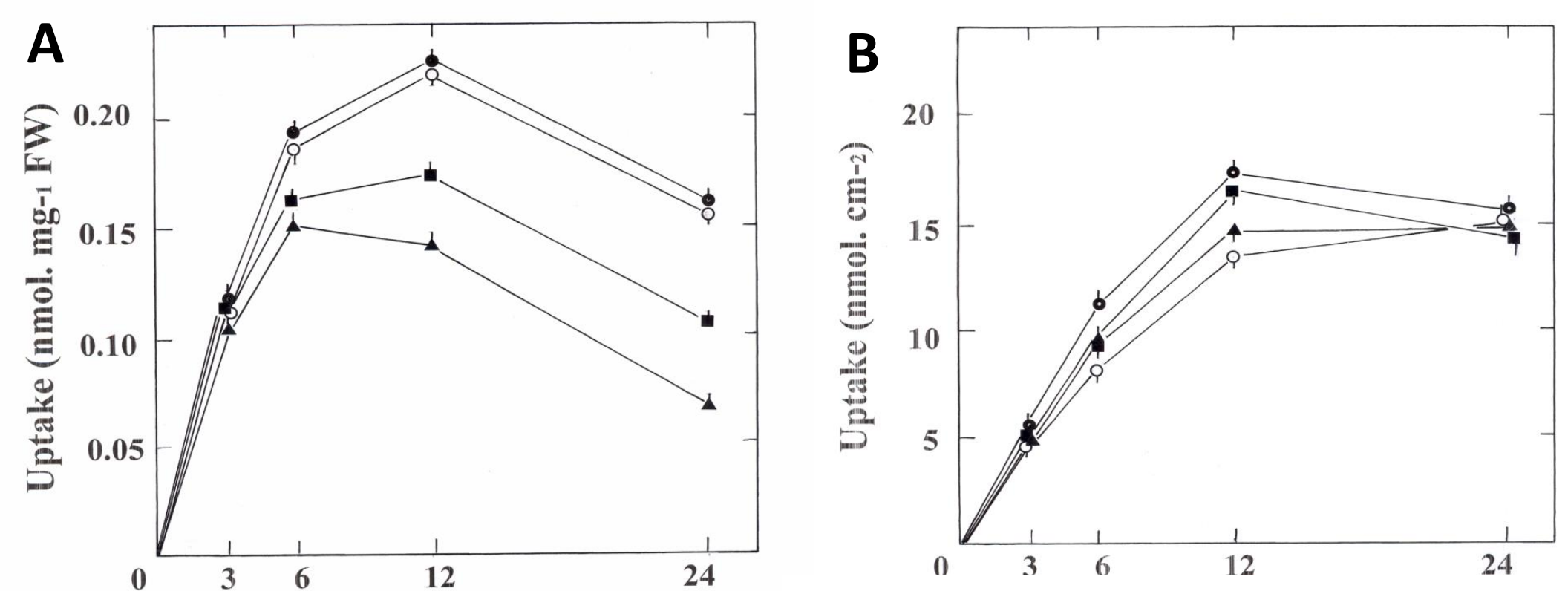

Figure 7
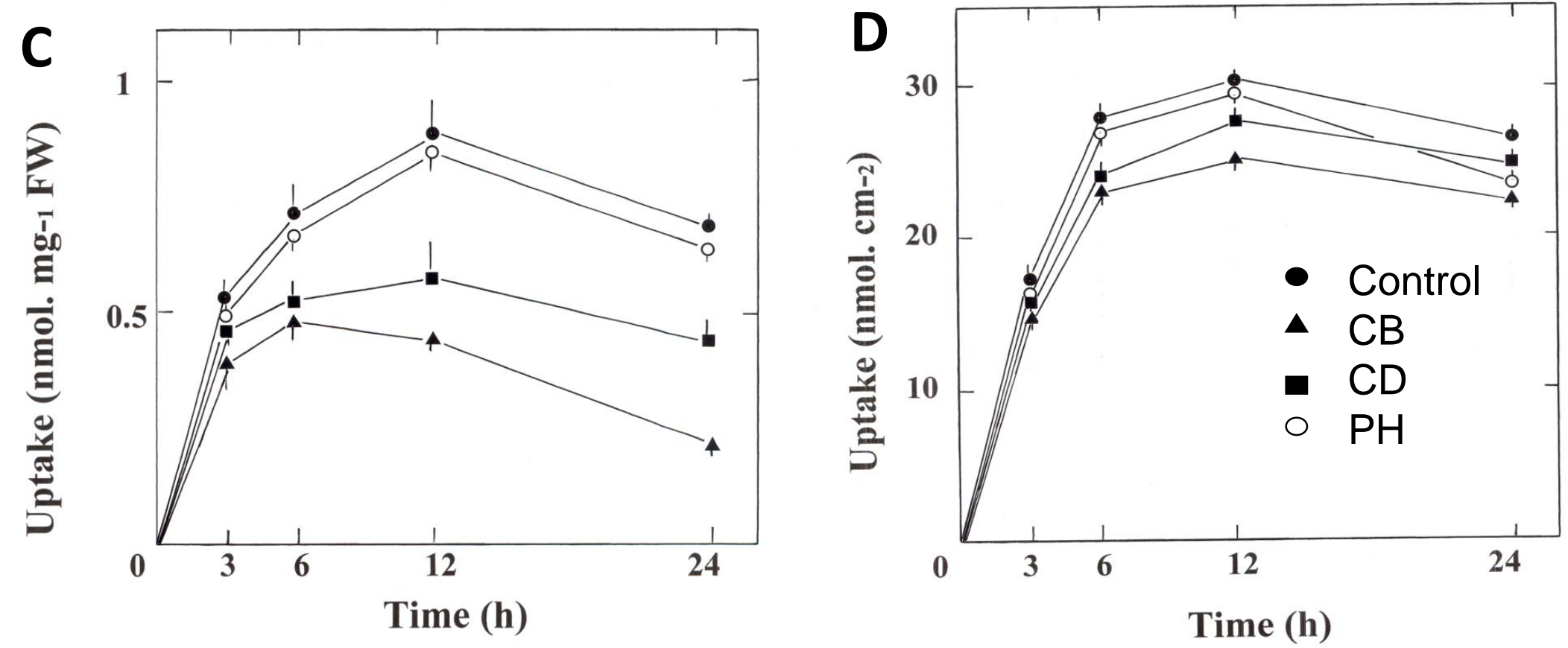


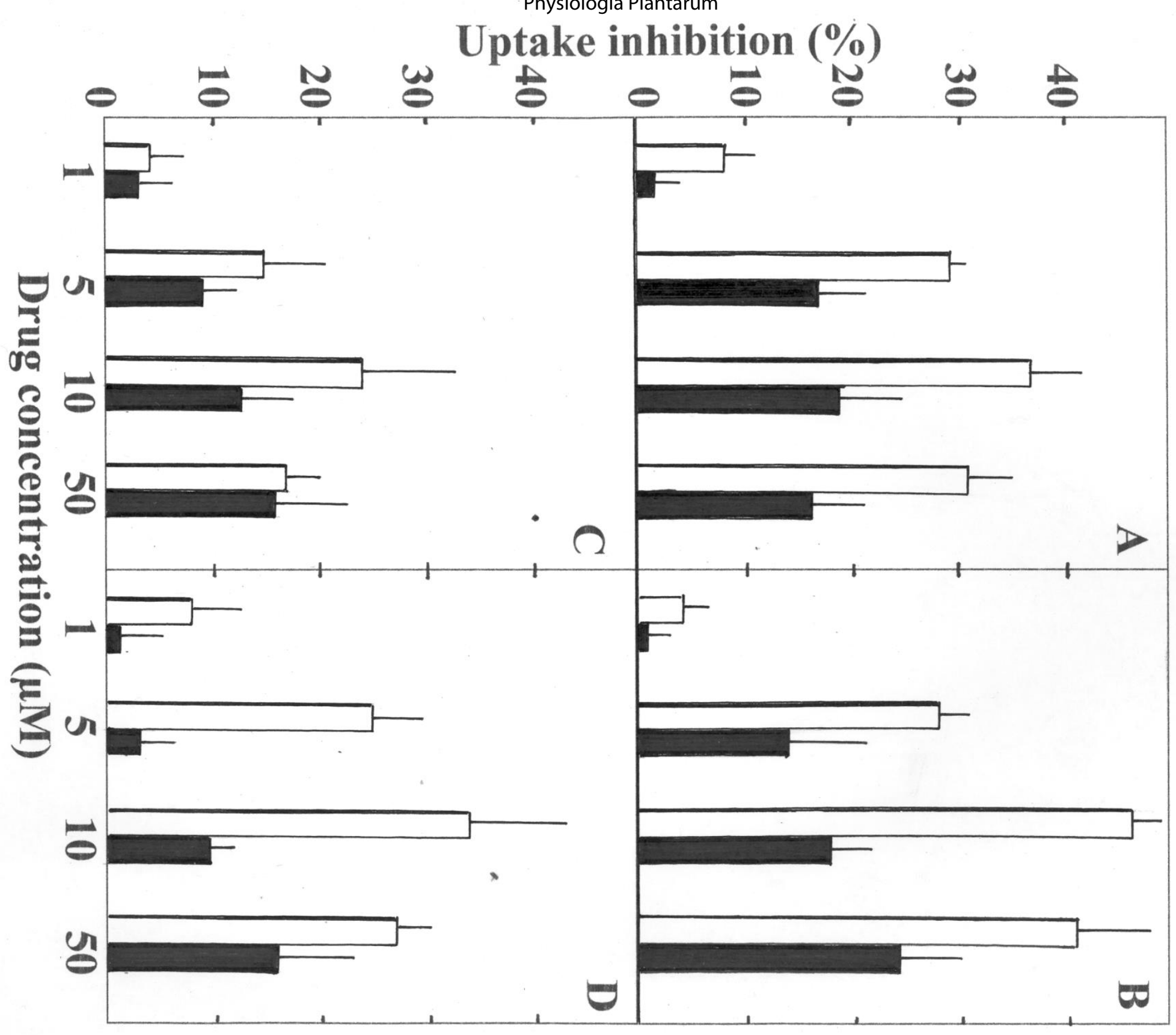


Figure 9

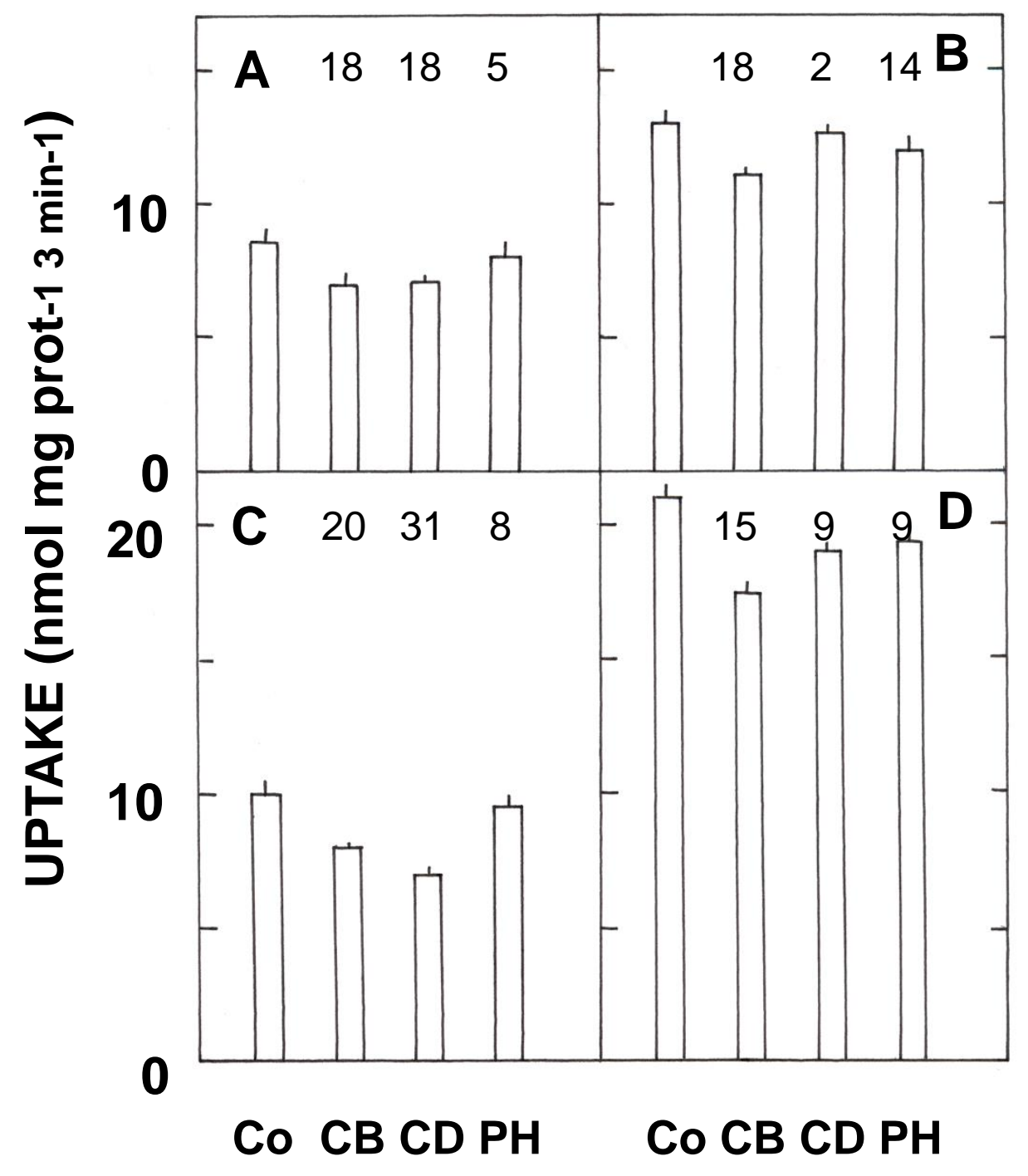

